US Army Corps

of Engineers .

Prepared for the U.S. Army Corps of Engineers, Portland District,

under an Interagency Agreement with the U.S. Department of Energy

Contract DE-AC05-76RL01830

\title{
Influence of Incision Location on Transmitter Loss, Healing, Incision Lengths, Suture Retention, and Growth of Juvenile Chinook Salmon
}

\section{Final Report}

JL Panther

RS Brown

GL Gaulke
CM Woodley

KA Deters

May 2010

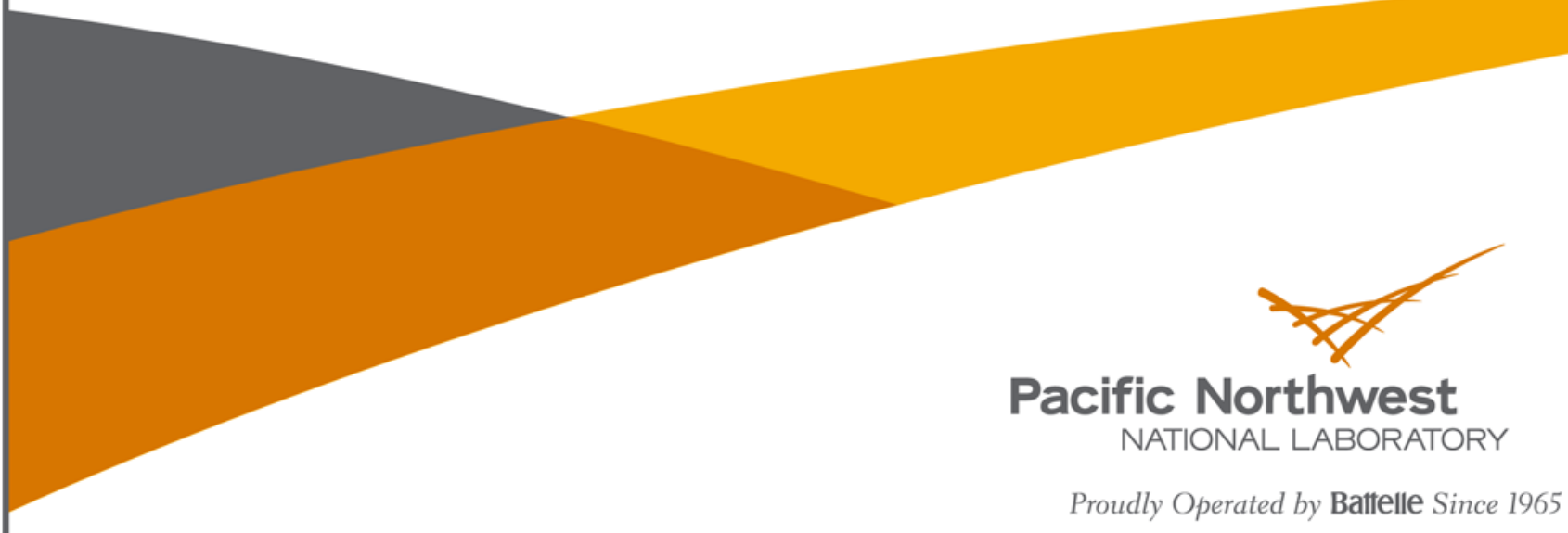




\section{DISCLAIMER}

This report was prepared as an account of work sponsored by an agency of the United States Government. Neither the United States Government nor any agency thereof, nor Battelle Memorial Institute, nor any of their employees, makes any warranty, express or implied, or assumes any legal liability or responsibility for the accuracy, completeness, or usefulness of any information, apparatus, product, or process disclosed, or represents that its use would not infringe privately owned rights. Reference herein to any specific commercial product, process, or service by trade name, trademark, manufacturer, or otherwise does not necessarily constitute or imply its endorsement, recommendation, or favoring by the United States Government or any agency thereof, or Battelle Memorial Institute. The views and opinions of authors expressed herein do not necessarily state or reflect those of the United States Government or any agency thereof.

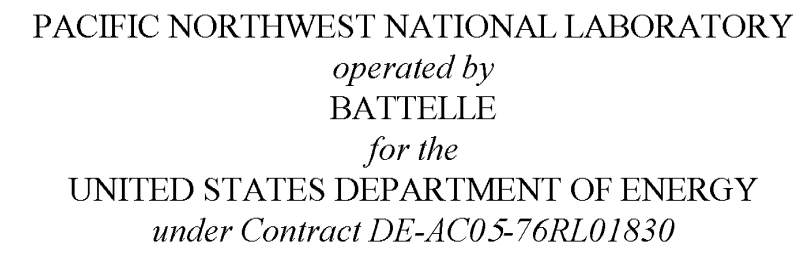

Printed in the United States of America

Available to DOE and DOE contractors from the Office of Scientific and Technical Information,

P.O. Box 62, Oak Ridge, TN 37831-0062; ph: (865) 576-8401 fax: (865) 576-5728

email: reports@adonis.osti.gov

\footnotetext{
Available to the public from the National Technical Information Service, U.S. Department of Commerce, 5285 Port Royal Rd., Springfield, VA 22161 ph: (800) 553-6847 fax: $(703) 605-6900$ email: orders@ntis.fedworld.gov online ordering: http://www.ntis.gov/ordering.htm
}

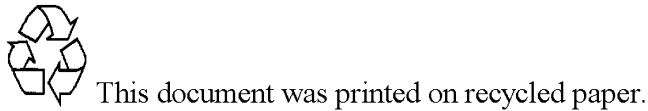




\title{
Influence of Incision Location on Transmitter Loss, Healing, Incision Lengths, Suture Retention, and Growth of Juvenile Chinook Salmon
}

\section{Final Report}

\author{
JL Panther \\ CM Woodley \\ RS Brown \\ KA Deters \\ GL Gaulke
}

May 2010

Prepared for

the U.S. Army Corps of Engineers, Portland District, under an Interagency Agreement with

the U.S. Department of Energy

Contract DE-AC05-76RL01830

Pacific Northwest National Laboratory

Richland, Washington 99352 


\section{Summary}

Many studies in fisheries research use acoustic and radio transmitters to track patterns in fish movements and estimate survival across populations. Currently, some researchers implant transmitters through an incision anterior to the pelvic girdle on the mid-ventral line (linea alba) of the fish to avoid bisecting muscle tissue. Others make an incision 2-10 mm lateral to and parallel to the linea alba to reduce disturbance of the incision site from the river bottom or tank. In the human medical literature, there is a growing trend in "muscle-sparing" incisions that follow the underlying muscle fibers, preserving muscle strength and integrity.

In this study, conducted by Pacific Northwest National Laboratory for the U.S. Army Corps of Engineers, Portland District, we measured differences in survival and growth, incision openness, transmitter loss, wound healing, and erythema among abdominal incisions on the linea alba, lateral and parallel to the linea alba (muscle-cutting), and following the underlying muscle fibers (muscle-sparing). A total of 936 juvenile Chinook salmon were implanted with both Juvenile Salmon Acoustic Telemetry System transmitters $(0.43 \mathrm{~g}$ dry $)$ and passive integrated transponder tags. Fish were held $a 2^{\circ} \mathrm{C}(n=$ $468)$ or $20^{\circ} \mathrm{C}(n=468)$ and examined once weekly over 98 days.

We found survival and growth did not differ among incision groups or between temperature treatment groups. Incisions on the linea alba had less openness than muscle-cutting and muscle-sparing incisions during the first 14 days when fish were held at $12^{\circ} \mathrm{C}$ or $20^{\circ} \mathrm{C}$. Transmitter loss was not different among incision locations by day 28 when fish were held at $12^{\circ} \mathrm{C}$ or $20^{\circ} \mathrm{C}$. However, incisions on the linea alba had greater transmitter loss than muscle-cutting and muscle-sparing incisions by day 98 at $12^{\circ} \mathrm{C}$. Results for wound closure and erythema differed among temperature groups. Results from our study will be used to improve fish-tagging procedures for future studies using acoustic or radio transmitters. 


\section{Acknowledgments}

This project would not have been possible without the help of many dedicated individuals.

Brad Eppard of the U.S. Army Corps of Engineers provided valuable insight on the methods and study design as well as support and encouragement throughout all phases of the study. Several staff from Pacific Northwest National Laboratory provided assistance. Special thanks to Andrew Solcz, Amanda Playter, Kathleen Carter, and Silvia Powell for their consistent availability for weekly observations. Jessica Allen's assistance with data organization and bibliographic entries was much appreciated. Ian Welch and James Boyd assisted on both days of surgery, and Jennifer Monroe assisted with doublechecking data. Craig McKinstry assisted in the initial statistical design.

Many thanks to John Skalski, Richard Townsend, and Adam Seaburg of the University of Washington for their guidance on statistical analysis.

Dennis Dauble, Brian Miller, Katie Panther, John Panther, and Virginia Panther provided much scientific advice. 


\section{Acronyms and Abbreviations}

$\begin{array}{ll}\text { ANODEV } & \begin{array}{l}\text { analysis of deviance } \\ \text { analysis of variance } \\ \text { fork length } \\ \text { FL }\end{array} \\ \text { g } & \text { gram(s) } \\ \text { IGR } & \text { Juventantaneous growth rate } \\ \text { JSATS } & \text { milligram(s) per liter } \\ \text { mg/L } & \text { millimeter(s) } \\ \text { mm } & \text { tricaine methanesulfonate } \\ \text { MS-222 } & \text { passive integrated transponder } \\ \text { PIT } & \text { Pacific Northwest National Laboratory } \\ \text { PNNL } & \text { U.S. Army Corps of Engineers, Portland District } \\ \text { USACE } & \end{array}$




\section{Contents}

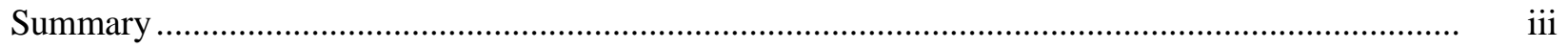

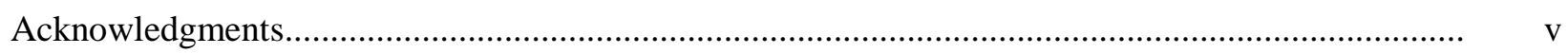

Acronyms and Abbreviations ....................................................................................................... vii

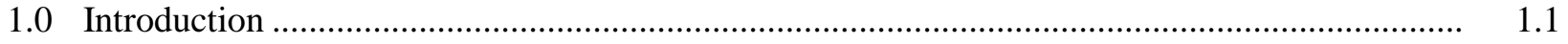

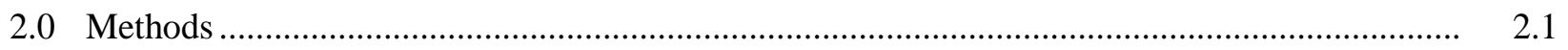

2.1 Study Site and Fish Care ............................................................................................ 2.1

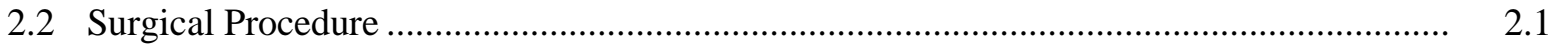

2.3 Macroscopic Evaluation.................................................................................... 2.2

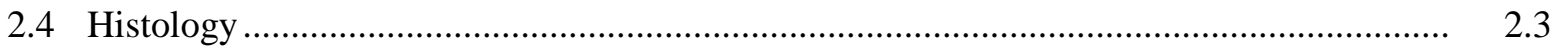

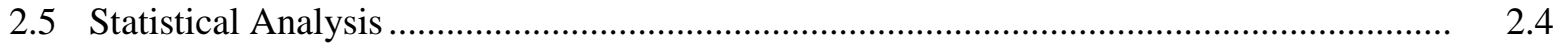

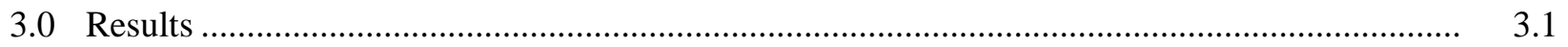

3.1 Transmitter Loss..............................................................................................................

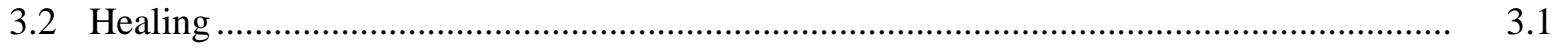

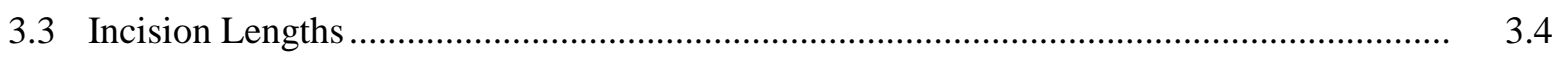

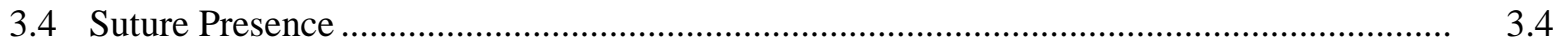

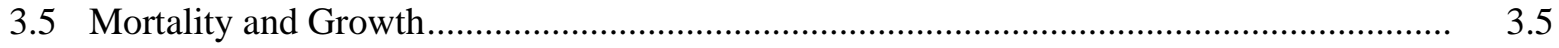

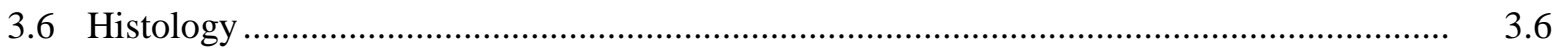

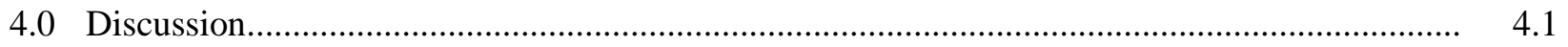

4.1 Transmitter Loss....................................................................................................... 4.1

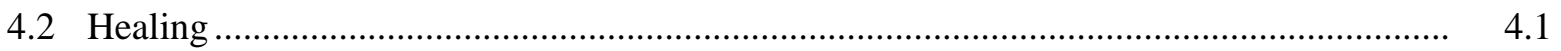

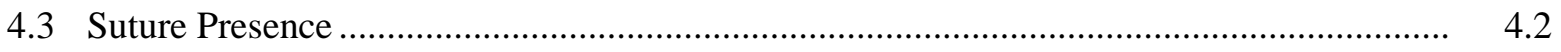

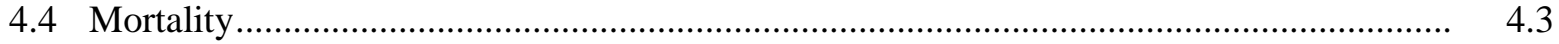

5.0 Conclusions and Recommendations.................................................................................

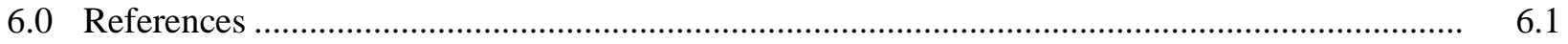

Appendix A - Detailed Statistical Analysis..................................................................................... A.1 


\section{Figures}

2.1 Criteria used to grade external appearance of tissue apposition of incision

3.1 Cumulative transmitter loss among juvenile Chinook salmon implanted with an acoustic transmitter and PIT tag through an incision on the linea alba, a muscle-cutting incision, or a muscle-sparing incision and held at $12^{\circ} \mathrm{C}$ or $20^{\circ} \mathrm{C}$

3.2 Open area of incisions in square millimeters and mean ranks of apposition scores among juvenile Chinook salmon implanted with an acoustic transmitter and PIT tag through an incision on the linea alba, a muscle-cutting incision, or a muscle-sparing incision and held at $12^{\circ} \mathrm{C}$ or $20^{\circ} \mathrm{C}$.

3.3 Percentage of incisions with erythema and incision closure among juvenile Chinook salmon implanted with an acoustic transmitter and PIT tag through an incision on the linea alba, a muscle-cutting incision, or a muscle-sparing incision and held at $12^{\circ} \mathrm{C}$ or $20^{\circ} \mathrm{C}$

3.4 Mean incision lengths among juvenile Chinook salmon implanted with an acoustic transmitter and PIT tag through an incision on the linea alba, a muscle-cutting incision, or a muscle-sparing incision and held at $12^{\circ} \mathrm{C}$ or $20^{\circ} \mathrm{C}$

3.5 Mean suture presence among juvenile Chinook salmon implanted with an acoustic transmitter and PIT tag through an incision on the linea alba, a muscle-cutting incision, or a muscle-sparing incision and held at $12^{\circ} \mathrm{C}$ or $20^{\circ} \mathrm{C}$

3.6 Transverse section of an incision on the linea alba, a muscle-cutting incision, and a musclesparing incision on day 14

3.7 Transverse section of an incision on the linea alba, a muscle-cutting incision, and a musclesparing incision on day 21

3.8 Transverse section of the three incision locations on day 98

3.9 Anomalous healing of an incision on the linea alba on day 98.

3.10 Anomalous healing of a muscle-sparing incision

\section{Tables}

2.1 Histological criteria used to evaluate wound healing in juvenile Chinook salmon implanted with an acoustic transmitter and PIT tag through one of three incision locations

3.1 Instantaneous growth rate, cumulative mortality, and transmitter loss over 98 days among juvenile Chinook salmon implanted with an acoustic transmitter and PIT tag through an incision on the linea alba, a muscle-cutting incision, or a muscle-sparing incision. 


\subsection{Introduction}

This report documents a study conducted by Pacific Northwest National Laboratory (PNNL) fisheries scientists for the U.S. Army Corps of Engineers, Portland District (USACE). The research was conducted in an attempt to derive surgical implantation methods that have minimal influence on fish used in survival studies within the Columbia River basin. The USACE uses survival studies to determine the influence of its facilities or operations on fish.

Surgical implantation of transmitters has become widely accepted for use in long-term studies of fish behavior using acoustic and radio telemetry (Winter 1996). The goal of surgically implanting transmitters remains the same across studies: to ensure the transmitter is retained within the fish long enough to collect the desired data while minimally impacting survival and behavior. Survival studies involving transmitter implantation operate under the assumption that the method of implantation does not influence the behavior and survival of the fish (Peven et al. 2005). However, surgical implantation is invasive by nature, requiring an incision that bisects skin and muscle tissue, which may adversely affect the health of the fish.

The primary function of the integument of teleost fish is to provide a barrier to pathogens in the surrounding aquatic environment (Roberts 1989). The integument also aids in osmoregulation and helps decrease friction when fish move through the water by producing mucus (see review by Shephard 1994). Numerous studies have demonstrated that the integument plays a vital role in maintaining internal homeostatis and protection from pathogens, and damage to the integument may lead to death (Noga 2000). For example, in Saprolegnia-infected brown trout (Salmo trutta), loss of serum electrolytes and protein was found to be proportional to the percentage of integument affected (Richards and Pickering 1979). Atlantic salmon (Salmo salar L.) affected by invasive ulcers or "winter sores" extending into the underlying musculature died from osmoregulatory problems or bacterial septicemia (Lunder 1992). Furthermore, Atlantic salmon with either artificial wounds or a non-intact mucus layer had higher mortality than controls when all three groups were exposed to bath challenges of Vibrio anguillarum (causative agent of vibriosis) and Aeromonas salmonicida (causative agent of furunculosis; Svendsen and Bogwald 1997). Damage to the integument can sometimes result in mortality, usually by increasing a fish's susceptibility to disease (Logan and Odense 1974) or decreasing efficient osmoregulation (Noga 2000).

In addition to disrupting the integument, surgical incisions on fish can bisect different types of tissue. Research comparing healing rates in different kinds of tissues within the same species of fish is sparse, and no experimental studies are known to exist. Although some studies mention anecdotal observations of incisions made in different locations (Pautzke and Meigs 1941), other studies consider only macroscopic appearance and transmitter loss among different incision locations (Schramm and Black 1984; Wagner and Stevens 2000; Dieterman and Hoxmeier 2009). In humans, healing takes longer in connective tissue with little or no blood supply, such as cartilage and tendons, than it does in tissue with highly perfused tissue such as muscle (Barbul 2005). The blood supply drives the inflammatory response and is essential for complete wound healing (Barbul 2005; Franz et al. 2008; Sen 2009). There is very little evidence that incisions in different types of fish tissue heal at different rates, and comparisons of healing among different fish tissues have not been well quantified with histology. 
The effects of temperature on wound healing and transmitter expulsion should be considered because healing rates are temperature mediated (Anderson and Roberts 1975) and temperature may influence transmitter expulsion (Knights and Lasee 1996; Bunnell et al. 1998; Bunnell and Isely 1999). Because fish are poikilotherms, their physiology, immune function, and rates of healing are influenced by environmental temperature (Anderson and Roberts 1975; Le Morvan et al. 1998). Most species at a given temperature have similar rates of response for phagocytosis, inflammation, and wound healing, as well as responses to toxic and septicaemic microbial diseases (Roberts 1989). However, as temperature increases, the rate of responses accelerates (Roberts 1989). For example, Ream et al. (2003) showed that as temperature increased, so did the motility of epithelial wound-healing cells (keratocytes), which migrate across wounded areas to inhibit infection (Radice 1980a, 1980b; Euteneuer and Schliwa 1984). Anderson and Roberts (1975) found the White Cloud Mountain minnow (Tanichthyes albonubes) experimentally wounded (2-4 mm long, 0.6-1 mm deep) with a scalpel healed more quickly when held at elevated temperatures than the Atlantic salmon (Salmo salar) held at lower temperatures. In addition to delaying the healing process, lower temperatures have led to immunosuppression (Bly and Clem 1992; Le Morvan et al. 1998; Nikoskelainen et al. 2004), which may influence the fish's ability to overcome any infection resulting from a surgical procedure. Studying differences in healing at both high and low temperatures may provide valuable insight into the healing process that might not be apparent at only one temperature.

Several locations for implantation of transmitters in fish have been mentioned in the literature. Incisions have been made in the connective tissue of the ventral midline (the linea alba; Marty and Summerfelt 1986; Lucas 1989; Knights and Lasee 1996; Wagner and Stevens 2000), across the white muscle tissue off and parallel to the linea alba, anterior to the pelvic girdle (hereafter termed musclecutting; Adams et al. 1998; Wagner and Stevens 2000), or perpendicular to and several millimeters from the linea alba (vertical incision; Cobb 1933; Schramm and Black 1984). The concept of an incision that followed the lines of the underlying myomeres (hereafter termed muscle-sparing) was mentioned by Pautzke and Meigs (1941). Research on the healing outcome of muscle-sparing incisions does not appear to exist.

The objective of this study was to determine differences in survival, transmitter loss, healing (as measured by incision closure, presence of abnormal redness of the skin around the incision [erythema] and histological indicators), growth, and suture retention among three incision types. The first incision was on the linea alba, the second was off and parallel to the linea alba (muscle-cutting), and the third extended from the linea alba toward the dorsum at a $45^{\circ}$ angle, between the parallel lines of myomeres (muscle-sparing). All three incisions were made in the same vicinity, anterior to the pelvic girdle. We hypothesized that fish with incisions on the linea alba would have better incision closure with less erythema than those with muscle-cutting and muscle-sparing incisions. We hypothesized that incisions on the linea alba would have a higher rate of transmitter loss because the transmitter rests partially or fully on the incision (Schramm and Black 1984). The effect of environmental temperature on all variables was considered by executing the same study at a high and a low temperature $\left(20^{\circ} \mathrm{C}\right.$ and $\left.12^{\circ} \mathrm{C}\right)$.

Results from this study will be used to guide the techniques used to surgically implant transmitters in juvenile salmonids used in survival studies. These results will also aid in providing a scientific basis for standardizing implantation techniques.

In this report, Section 2 documents the study methods. The study results are presented in Section 3 and discussed in Section 4. Our conclusions and recommendations are presented in Section 5. Sources 
cited are listed in Section 6. An appendix documents the outcomes of statistical analyses in a series of tables. 


\subsection{Methods}

\subsection{Study Site and Fish Care}

Juvenile fall Chinook salmon (Oncorhynchus tschawyscha), originally obtained as eyed eggs from the McKenzie River Hatchery in Leaburg, Oregon, were raised at the Aquatic Research Laboratory at Pacific Northwest National Laboratory (PNNL) in Richland, Washington. Fish used in the study (95-121 mm fork length [FL], mean $105 \mathrm{~mm}$ ) were stocked into two indoor circular tanks (1.2 m in diameter and $0.5 \mathrm{~m}$ deep, each holding $608 \mathrm{~L}$ of water), and the lights in the laboratory automatically simulated the natural photoperiod. Water temperature was maintained at $12 \pm 1^{\circ} \mathrm{C}$ and $20 \pm 1^{\circ} \mathrm{C}$ with flow-through well water, and fish were held at desired temperatures for 14 days prior to surgery. Fish were fed a daily maintenance ration of BioDiet Starter moist pellets (Bio-Oregon, Longview, Washington); food was withheld 24 hours prior to anesthetization for surgical implantation and weekly observations. The maintenance, handling, and testing procedures for the fish were approved by the PNNL Animal Care Committee, which meets the standards of the American Association for Accreditation of Laboratory Animal Care.

\subsection{Surgical Procedure}

The first trial was performed at $12^{\circ} \mathrm{C}$ in October 2008 , and a second trial was performed at $20^{\circ} \mathrm{C}$ in February 2009. For each temperature trial, fish were selected randomly to create four groups of 156 fish each (three incision treatments and one control). An initial power analysis performed on a pilot study found that 104 fish per incision location were required to detect a 5\% difference among locations (with 95\% confidence and 80\% power). An additional 52 fish were included to provide fish to collect for histology and to provide an even number of fish per surgeon. Because the final sample size was 156 fish per treatment, three surgeons were required to perform all of the surgeries in one day.

Fish were individually anesthetized in a concentration of $80 \mathrm{mg}$ of tricaine methanosulfonate [MS-222]/L of water) until they reached stage 4 anesthesia (Summerfelt and Smith 1990) and then weighed (grams) and measured (fork length, millimeters) before being placed on a V-shaped neoprene trough. The trough was coated with a water conditioner (PolyAqua, Kordon LLC, Hayward, California) to protect the mucus layer, and a soft rubber tube was inserted in the fish's mouth to continuously perfuse the gills with a maintenance dose of anesthetic (40 mg/L MS-222). Control fish were anesthetized, weighed, and measured similar to treatment fish but did not undergo surgery.

Prior to surgery, transmitters were disinfected by immersion in 70\% ethanol for 10 minutes, and surgical instruments were autoclaved. Instruments were disinfected by immersion in $70 \%$ ethanol for 8-10 minutes and rinsed in deionized water between each operation to minimize the spread of aquatic pathogens among fish. All surgeons wore sterile medical examination gloves. According to a predetermined random order, a 7- to 9-mm incision was made at one of three locations. The first was on the linea alba, the second was $3 \mathrm{~mm}$ from and parallel to the linea alba anterior to the pelvic girdle (muscle-cutting), and the third extended from the linea alba dorsally and posteriorly at approximately a $45^{\circ}$ angle (between the myomeres; muscle-sparing). Both a Juvenile Salmonid Acoustic Telemetry System (JSATS) acoustic transmitter $(12.0 \times 5.3 \times 3.7 \mathrm{~mm}$, and $0.44 \mathrm{~g}$ in air, $0.30 \mathrm{~g}$ in water, $0.144 \mathrm{~mL})$ and a passive integrated transponder (PIT) tag $(12.5 \times 2.1 \mathrm{~mm}, 0.10 \mathrm{~g}$ in air, 0.06 in water, $0.036 \mathrm{~mL})$ were implanted in the body cavity of the fish. The fish were double-tagged to simulate field studies on 
the Snake and Columbia rivers where the presence of a PIT tag prevents fish from being sorted into transport barges or trucks at juvenile bypass facilities. Incisions were closed with two simple interrupted 5-0 Monocryl sutures (Ethicon, Rahway, New Jersey) approximately 2-3 mm apart.

Immediately following surgery, fish were placed ventral-side up on a different V-shaped neoprene trough coated with PolyAqua, and an image of the incision was taken with a PixeLINK PL-A66X FireWire camera (0.5x magnification lens; Ottawa, Ontario, Canada) attached to a Zeiss microscope (0.65x magnification; Chester, Virginia). Fish were placed in a recovery bucket with bubbled air and, upon full recovery, were returned to a circular tank. All treatment and control fish were held in the same circular tank.

\subsection{Macroscopic Evaluation}

Incisions on fish were examined, imaged, and graded once a week post-surgery during a period of 98 days. Treatment and control fish were individually anesthetized (80 mg/L MS-222), weighed, measured, and placed on a V-shaped neoprene trough coated with PolyAqua. During these weekly evaluations, a soft rubber tube was inserted in the fish's mouth to continuously perfuse the gills with a maintenance dose of $40 \mathrm{mg} / \mathrm{L}$ MS-222, and the incision site was photographed with the same microscope camera previously described. One trained individual determined the presence or absence of the sutures, incision closure and apposition, and the presence of erythema on the incisions. After they were examined, fish were placed in a recovery bucket with bubbled air and, upon full recovery, were returned to the holding tank.

Incision closure was defined as the point when the incision edges were touching and scale regeneration was nearly complete, similar to Walsh et al. (2000). The point at which incision closure occurred was a qualitative assessment made by the observer to define when the incision appeared "healed." Erythema in the incision was defined as any visible redness on the surface of the scales and integument. Other studies have referred to redness around the incision as inflammation (Hart and Summerfelt 1975; Walsh et al. 2000; Lowartz et al. 1999; Deters et al.2010), erythema (Hart and Summerfelt 1975), or exudate (Lowartz et al. 1999; Cunha da Silva et al. 2005). The criteria in Figure 2.1 were used to score apposition of the incision. Scores represented the proportion of the incision that was apposed, folding inward, overlapping, and/or gaping apart. Similar to Wynne et al. (2004), apposition scores (Figure 2.1) were ranked for analysis according to the following:

1. no separation of layers (score of “1,” “2,” “ 1,2, , or “ 5 ”)

2. < $50 \%$ superficial separation (score of “1,6,” “2,6,” “3,6,” or “4,6”)

3. > 50\% superficial separation (score of “ 1,7, , “ 2,7, , or “ 3,7 ”)

4. $100 \%$ separation of layers (score of “8”).

Incision lengths and openness were measured on digital images of the incisions using Image-Pro Plus Version 6.2 digital imaging software (Media Cybernetics, Inc., Bethesda, Maryland). Incision lengths were measured by calibrating the measuring tool to a scale bar in the image and tracing the incision line from one end to the other. For incisions whose apposition scores indicated partial or full openness (Figure 2.1), the open area was measured by outlining the perimeter of the incision where scales ceased and muscle-tissue and viscera were visible in the incision. Any tissue around the incision that was damaged by the tearing of a suture was excluded from the open area that was measured. 
Review of the digital images of fish held at $20^{\circ} \mathrm{C}$ revealed that $34(65 \%)$ of one surgeon's fish with muscle-sparing incisions were perpendicular to the linea alba rather than between the myomere lines. Therefore, these fish were excluded from analysis.

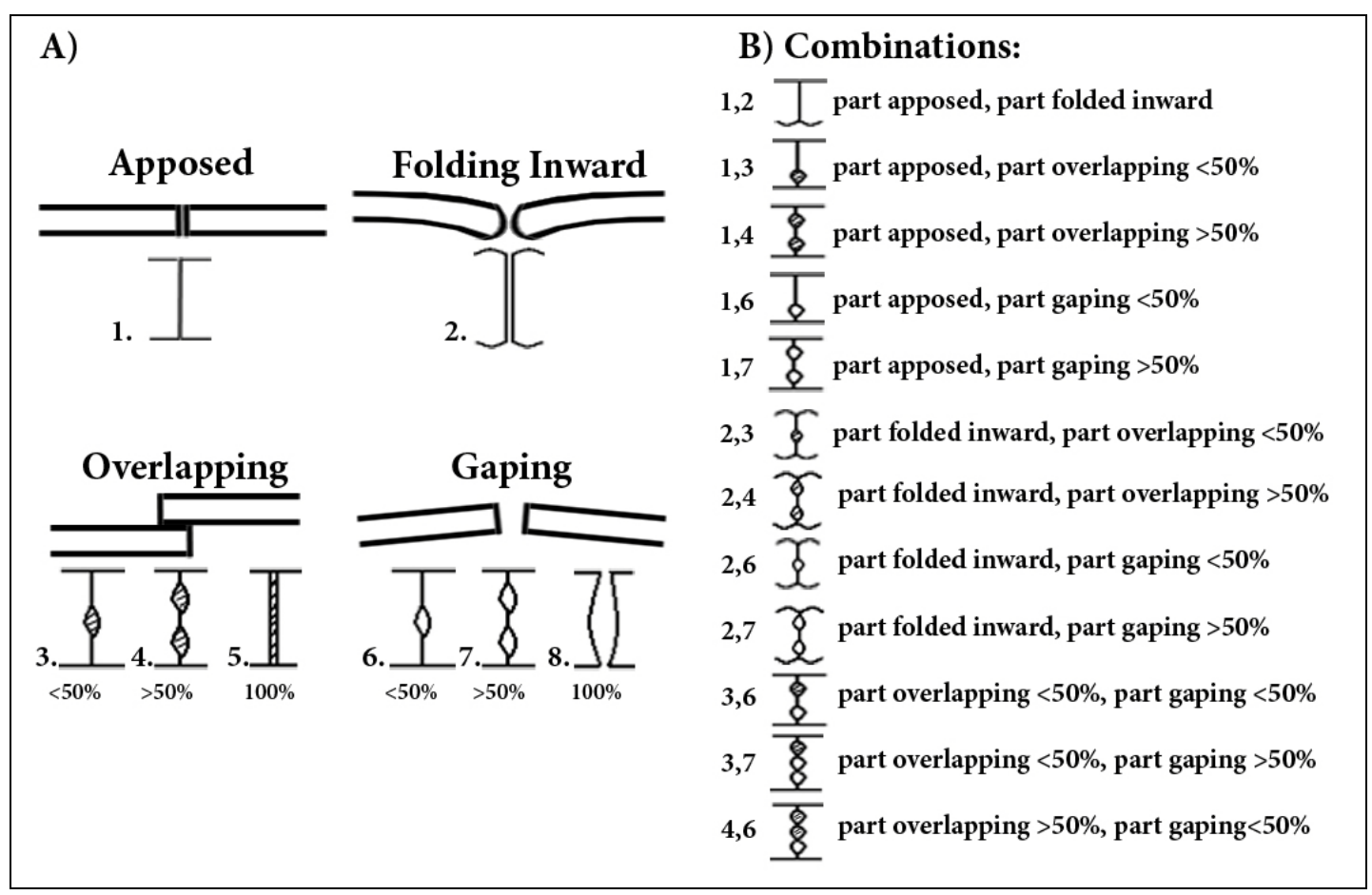

Figure 2.1. Criteria used to grade external appearance of tissue apposition of incision. A) Eight possible outcomes of apposition (apposed, folding inward, some portion overlapping, some portion gaping); B) combinations of the possible outcomes; i.e., " 1,4 " would mean more than $50 \%$ of the edges were overlapping and the rest was apposed.

\subsection{Histology}

Tissue samples were collected for histological examination from both temperature groups on days 0 , $3,7,10,14,21,42$, and 98 following surgery. Three fish from each treatment group and one fish from each control group at each time point were examined. All fish were euthanized in $250 \mathrm{mg} / \mathrm{L}$ of MS-222, and fish tissue samples were prepared similar to the method in Elston et al. (1997). A rectangular-shaped area of tissue around the incision approximately $3 \times 2 \mathrm{~cm}$ was excised. Tissue samples were immersionfixed with $10 \%$ buffered neutral formalin for 48 hours and stored in formalin. Tissues were processed by conventional paraffin embedding and stained with hematoxylin and eosin. Three transects were made across each incision. The first transect was made between the anterior end of the incision and the rostral suture, the second was directly across the middle of the incision, and the third was between the caudal suture and the posterior end of the incision. Due to a processing error, many of the transects between the anterior end of the incision and the rostral suture were sectioned incorrectly and did not include the incision; therefore, none of these incisions were included in the analysis. Single-blind histological analysis was performed on the two remaining transects per incision using the criteria in Table 2.1, and ratings for the two sections were averaged for each fish. 


\subsection{Statistical Analysis}

Binary data (incision closure, incision erythema, and transmitter loss) were analyzed with a generalized linear model using a binomial error structure and a logit link function via analysis of deviance (ANODEV). Continuous variables (incision openness, mean suture presence, incision lengths, and ranks of incision apposition scores) were analyzed with ANOVA with repeated measures through day 28 because the majority of fish within the field study supported by this laboratory study have migrated to the ocean within 28 days (Smith et al. 2003). ANOVA with repeated measures was not used through day 98 (except with mean suture presence) because values approached or remained at zero from day 35 through day 98, obscuring or eliminating the correlations between weeks that repeated measures determine. Therefore, ANOVA without repeated measures was used on days of biological significance and days of significance to project goals. Ranks of apposition scores were considered continuous variables because the ranks were based on an underlying continuous scale (Snedecor and Cochran 1989). Pairwise comparisons were made among incision locations and surgeons with a Bonferonni correction. An alpha of 0.05 was used for all tests.

The main effects of incision location on all variables were evaluated. Results of the three surgeons remained pooled regardless of interactions, making the results applicable to most surgeons with similar techniques or to many research projects in which multiple surgeons are required because of large sample sizes. Temperature was not included as a factor because of size differences between the two groups and the elapsed time between research on the two groups (4 months apart). However, general comparisons between groups of fish held at $12^{\circ} \mathrm{C}$ and $20^{\circ} \mathrm{C}$ were still made.

The instantaneous growth rates (IGRs) of treated fish were calculated with the formula from Isely and Grabowski (2007, p. 204, Equation 5.7):

$$
G=\left(\log _{e} L_{2}-\log _{e} L_{1}\right) /\left(t_{2}-t_{1}\right)
$$

where $L_{2}$ and $L_{1}$ are the lengths at $t_{2}$ and $t_{1}$ (time). Results were analyzed with ANOVA. Control fish were included in the study only to determine if mortality (if any) was caused by something other than the surgery (i.e., waterborne pathogens), and these fish were not individually marked. Therefore, growth rates were not calculated for control fish. 


\subsection{Results}

\subsection{Transmitter Loss}

Transmitter loss was influenced by water temperature and the time from implantation. Among fish held at $12^{\circ} \mathrm{C}$, fish with incisions on the linea alba generally had the highest transmitter loss rate among incision types over the entire course of the study. However, much of the transmitter loss occurred later in the experiment. Transmitter loss was not significantly different $(P>0.05)$ among incision types through day 28, when transmitter loss began steadily increasing for incisions on the linea alba (Figure 3.1). However, by day 98 , fish with incisions on the linea alba had significantly $(P=0.003)$ greater transmitter loss than fish with muscle-cutting and muscle-sparing incisions.

Among fish held at $20^{\circ} \mathrm{C}$, transmitter loss occurred sooner and over a smaller time period (Figure 3.1). The majority of transmitter loss occurred between 18 and 24 days after implantation. During this period, seven transmitters were lost on 7 consecutive days (one transmitter each day) through incisions on the linea alba. However, there was not a significant difference $(P=0.137)$ in transmitter loss among incision types during the 98-day holding period.

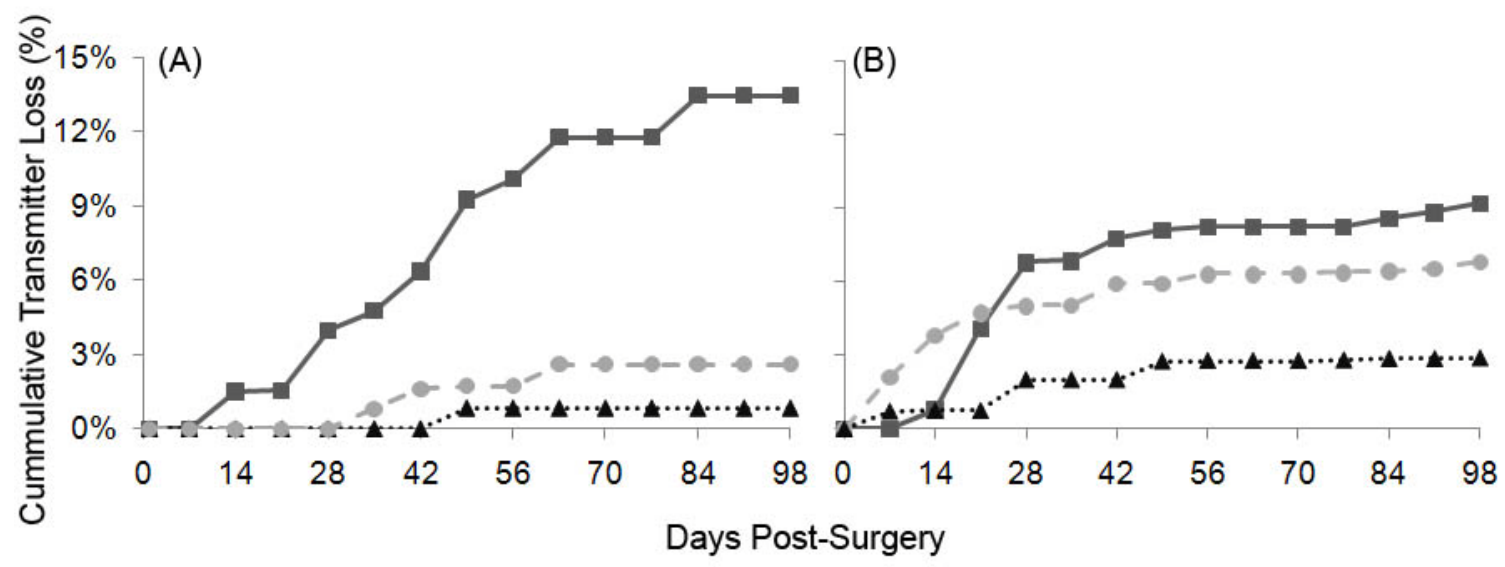

Figure 3.1. Cumulative transmitter loss among juvenile Chinook salmon implanted with an acoustic transmitter and PIT tag through an incision on the linea alba (--), a muscle-cutting $\left({ }^{-}-\right)$ incision, or a muscle-sparing (*^) incision and held at $12^{\circ} \mathrm{C}(\mathrm{A})$ or $20^{\circ} \mathrm{C}(\mathrm{B})$

\subsection{Healing}

The open area among incision types was significantly different $(P<0.001)$ during the first 21 days at both temperatures (Figure 3.2). When fish were held at $12^{\circ} \mathrm{C}$, incisions on the linea alba were significantly $(P<0.001)$ less open than muscle-cutting and muscle-sparing incisions on days 7,14 , and 21 and significantly $(P=0.031)$ less open than muscle-cutting incisions on day 28 . When fish were held at $20^{\circ} \mathrm{C}$, incisions on the linea alba were significantly $(P<0.002)$ less open than muscle-cutting and muscle-sparing incisions on days 7 and 14 , and less open than muscle-sparing incisions on day $21(P=$ 0.013). The open area of muscle-cutting and muscle-sparing incisions peaked on day 14 at $12^{\circ} \mathrm{C}$ and on 
day 7 at $20^{\circ} \mathrm{C}$. However, the open area of incisions on the linea alba peaked later on day 56 at $12^{\circ} \mathrm{C}$ and on day 21 at $20^{\circ} \mathrm{C}$.

Incision apposition ranks differed significantly $(P<0.001)$ among incision types during the first 28 days at both temperatures (Figure 3.2). Apposition ranks for incisions on the linea alba were significantly $(P<0.001)$ lower (indicating better incision apposition) than muscle-cutting and muscle-sparing incisions on days 7 and 14 at both temperatures and on day $21(P<0.001)$ for fish held at $12^{\circ} \mathrm{C}$. However, at $12^{\circ} \mathrm{C}$, incisions on the linea alba had significantly $(P<0.05)$ higher apposition ranks than muscle-cutting and muscle-sparing incisions from days 42 through 98 . When fish were held at $20^{\circ} \mathrm{C}$, apposition ranks did not differ $(P=1.000)$ among incision types from day 21 through the end of the study.
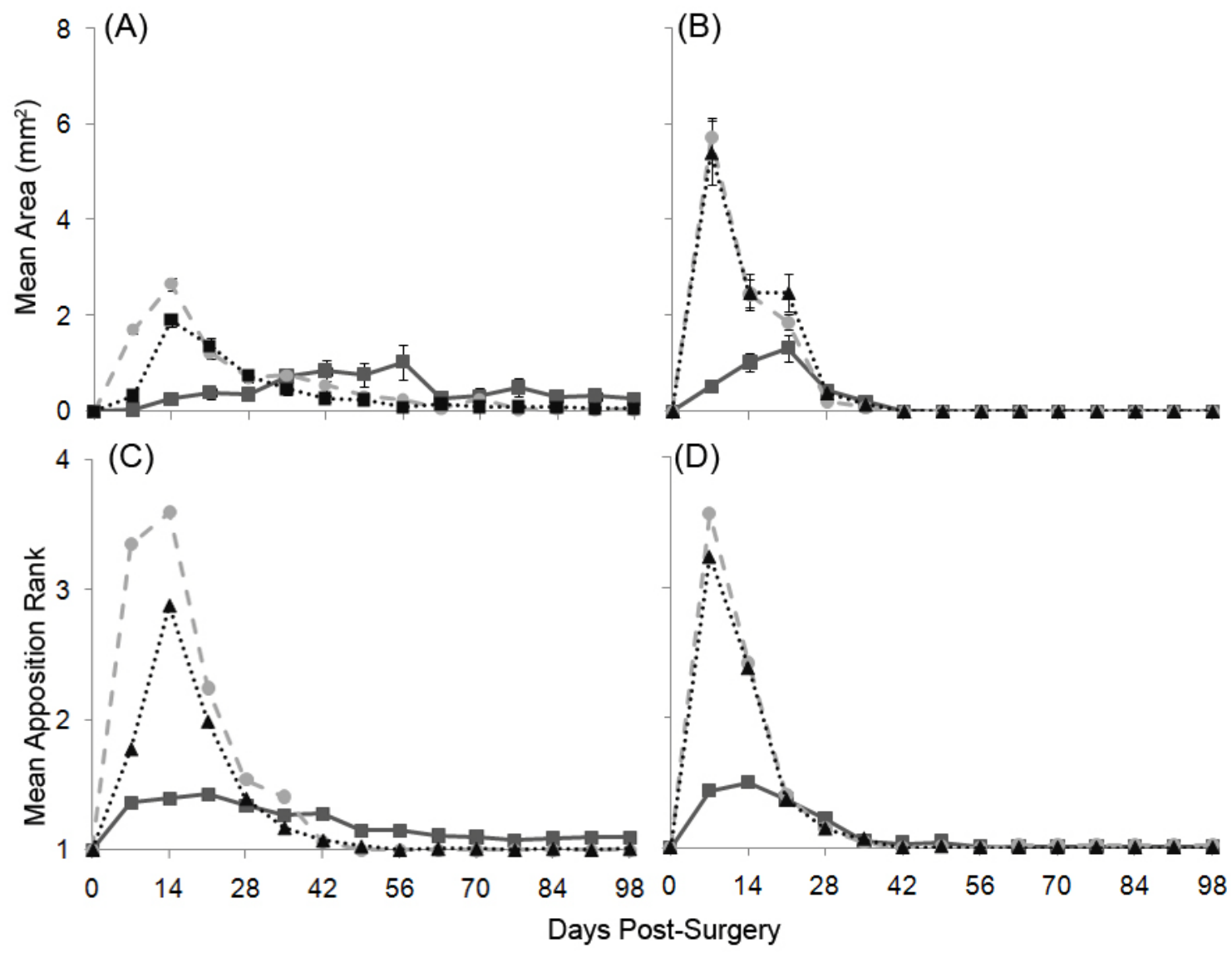

Figure 3.2. Open area of incisions in square millimeters (A, B) and mean ranks of apposition scores (C, D) among juvenile Chinook salmon implanted with an acoustic transmitter and PIT tag through an incision on the linea alba (--), a muscle-cutting (-๑) incision, or a muscle-sparing (**) incision and held at $12^{\circ} \mathrm{C}(\mathrm{A}, \mathrm{C})$ or $20^{\circ} \mathrm{C}(\mathrm{B}, \mathrm{D})$. A lower apposition rank indicates better apposition. Error bars represent standard error.

Trends of erythema on incisions differed among incision types based on water temperature and time from implantation. At $12^{\circ} \mathrm{C}$, significantly $(P<0.05)$ more muscle-cutting incisions than muscle-sparing incisions had erythema on days 14 and 28, and significantly $(P<0.001)$ more muscle-sparing incisions had erythema than incisions on the linea alba on days 7 and 14 (Figure 3.3). However, among fish held at $12^{\circ} \mathrm{C}$, significantly $(P<0.05)$ more incisions on the linea alba had erythema than muscle-sparing incisions on days 42 and 49 and muscle-cutting incisions on day 49 . Among fish held at $20^{\circ} \mathrm{C}$, 
significantly $(P<0.05)$ more incisions on the linea alba had erythema than muscle-sparing incisions on day 14 and muscle-cutting incisions on days 14 and 21. Significantly $(P=0.003)$ more muscle-cutting incisions than muscle-sparing incisions had erythema on day 7 at $20^{\circ} \mathrm{C}$.

Differences in incision closure (point at which incisions appeared healed) among incision types were influenced by water temperature and time from implantation (Figure 3.3). There was no significant difference $(P=1.000)$ in incision closure among incision types from days 7 through 21 at $12^{\circ} \mathrm{C}$. By day 28 , significantly $(P<0.01)$ more incisions on the linea alba were closed than muscle-cutting or musclesparing incisions on fish held at $12^{\circ} \mathrm{C}$. Over time, this trend reversed, and from days 70 through 91 , significantly $(P<0.05)$ more muscle-sparing and muscle-cutting incisions were closed than incisions on the linea alba. By day 98, 12\% of incisions on the linea alba were still not closed. Among fish held at $20^{\circ} \mathrm{C}$, there was no significant difference $(P=1.000)$ in incision closure among incision types except on day 21 when significantly $(P<0.001)$ more incisions on the linea alba were closed than muscle-cutting and muscle-sparing incisions. Among fish held at $20^{\circ} \mathrm{C}$, at least $75 \%$ of all three incision types were closed by day 28, and 99\% were closed by day 63 .
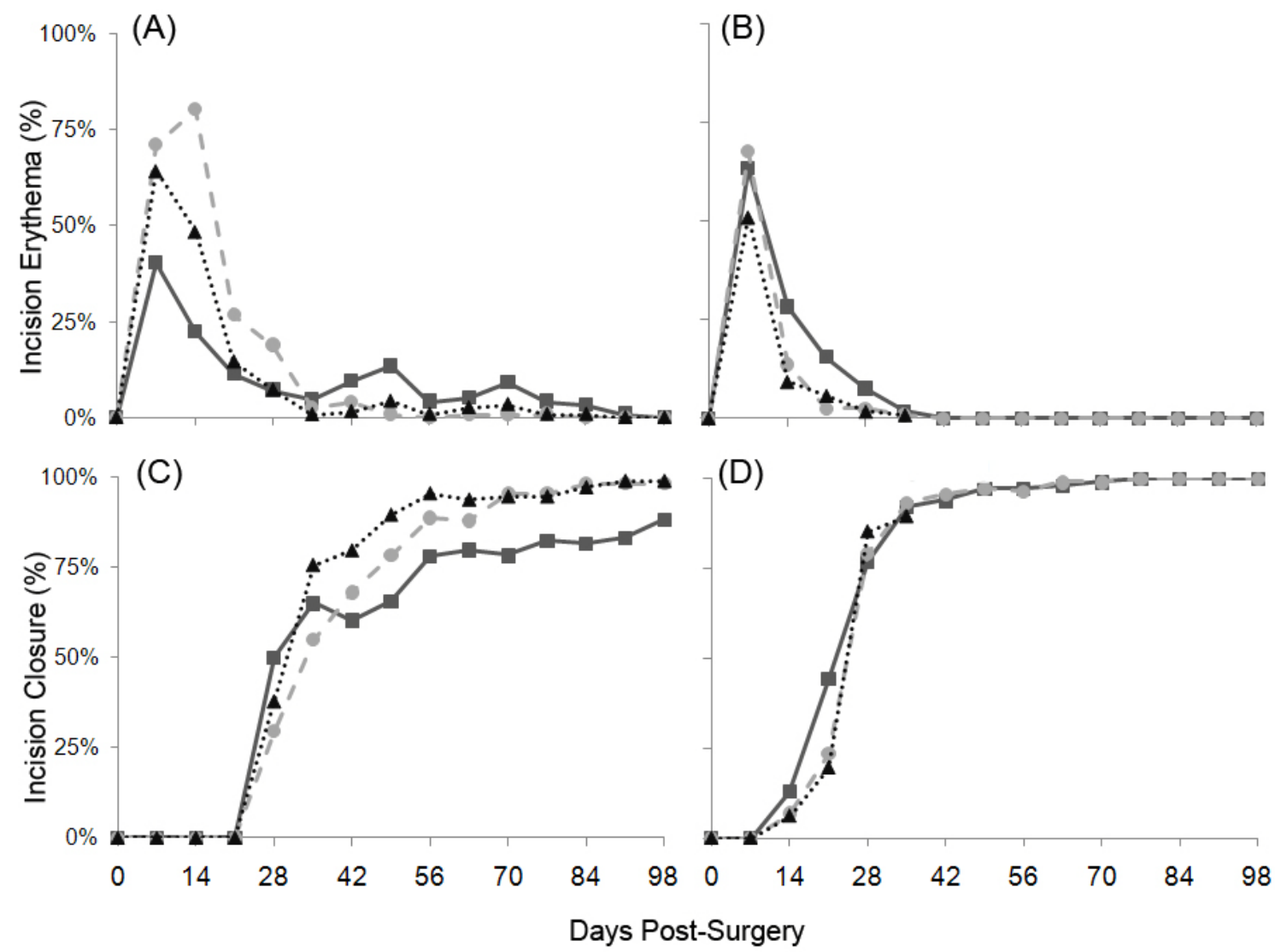

Figure 3.3. Percentage of incisions with erythema (A, B) and incision closure (C, D) among juvenile Chinook salmon implanted with an acoustic transmitter and PIT tag through an incision on the linea alba $\left({ }^{-}\right)$, a muscle-cutting $\left({ }^{-}-\right)$incision, or a muscle-sparing $\left(\cdot{ }^{*} \cdot\right)$ incision and held at $12^{\circ} \mathrm{C}(\mathrm{A}, \mathrm{C})$ or $20^{\circ} \mathrm{C}(\mathrm{B}, \mathrm{D})$ 


\subsection{Incision Lengths}

Incision lengths differed with water temperature and incision type. Mean lengths among incision types ranged from 7.0 to $7.9 \pm 0.06 \mathrm{~mm}$ at $12^{\circ} \mathrm{C}$ and from 7.5 to $8.0 \pm 0.07 \mathrm{~mm}$ at $20^{\circ} \mathrm{C}$ (Figure 3.4). Mean lengths of incisions on the linea alba were significantly $(P<0.001)$ longer $(7 \%$ on average) than muscle-cutting and muscle-sparing incisions at both temperatures. Muscle-sparing incisions were significantly $(P<0.001)$ shorter (by $7 \%)$ than muscle-cutting incisions at $12^{\circ} \mathrm{C}$ but not significantly different $(P=1.00)$ at $20^{\circ} \mathrm{C}$.

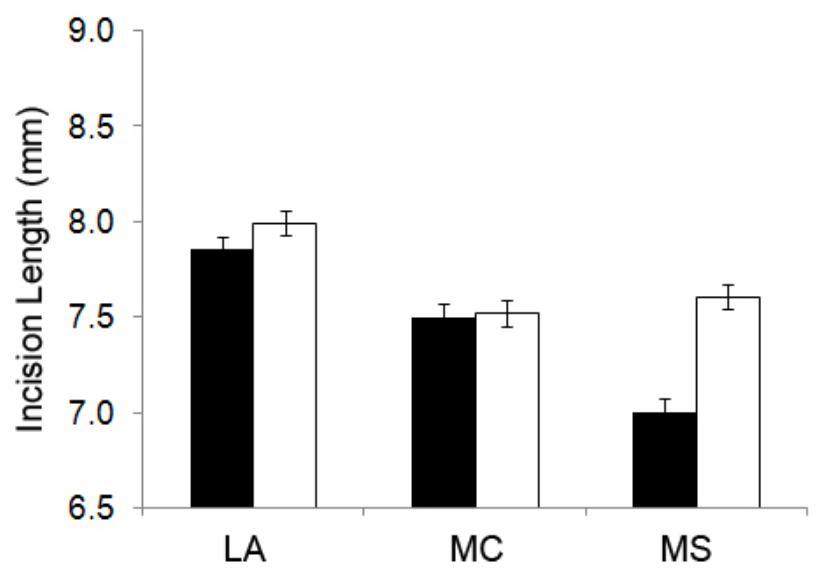

Figure 3.4. Mean incision lengths $( \pm \mathrm{SE})$ among juvenile Chinook salmon implanted with an acoustic transmitter and PIT tag through an incision on the linea alba (LA), a muscle-cutting (MC) incision, or a muscle-sparing (MS) incision and held at $12^{\circ} \mathrm{C}$ (black bars $\mathbf{m}$ ) or $20^{\circ} \mathrm{C}$ (white bars $\square)$. Error bars represent standard error.

\subsection{Suture Presence}

Fish with muscle-sparing incisions lost their sutures significantly $(P<0.05)$ more quickly than those with muscle-cutting incisions or incisions on the linea alba at both temperatures. There was no significant difference $(P>0.05)$ in mean suture retention between incisions on the linea alba and muscle-cutting incisions at $12^{\circ} \mathrm{C}$ and only on days $7(P<0.001)$ and $14(P=0.014)$ at $20^{\circ} \mathrm{C}$, when incisions on the linea alba had higher suture retention than muscle-cutting incisions (Figure 3.5$)$. At $12^{\circ} \mathrm{C}$, incisions on the linea alba had significantly $(P<0.05)$ greater mean suture retention than muscle-sparing incisions on days 21,28 , and 49 through 98 . Among fish held at $12^{\circ} \mathrm{C}$, mean suture retention for muscle-cutting incisions was significantly $(P<0.05)$ greater than muscle-sparing incisions on days 28, 84, and 98.

Among fish held at $20^{\circ} \mathrm{C}$, suture retention differed between incisions on the linea alba and muscle-sparing incisions on days 14 through 84, with incisions on the linea alba having significantly $(P<0.05)$ greater mean suture retention. At $20^{\circ} \mathrm{C}$, muscle-cutting incisions had significantly $(P<0.05)$ greater mean suture retention than muscle-sparing incisions on days 21 through 77. 


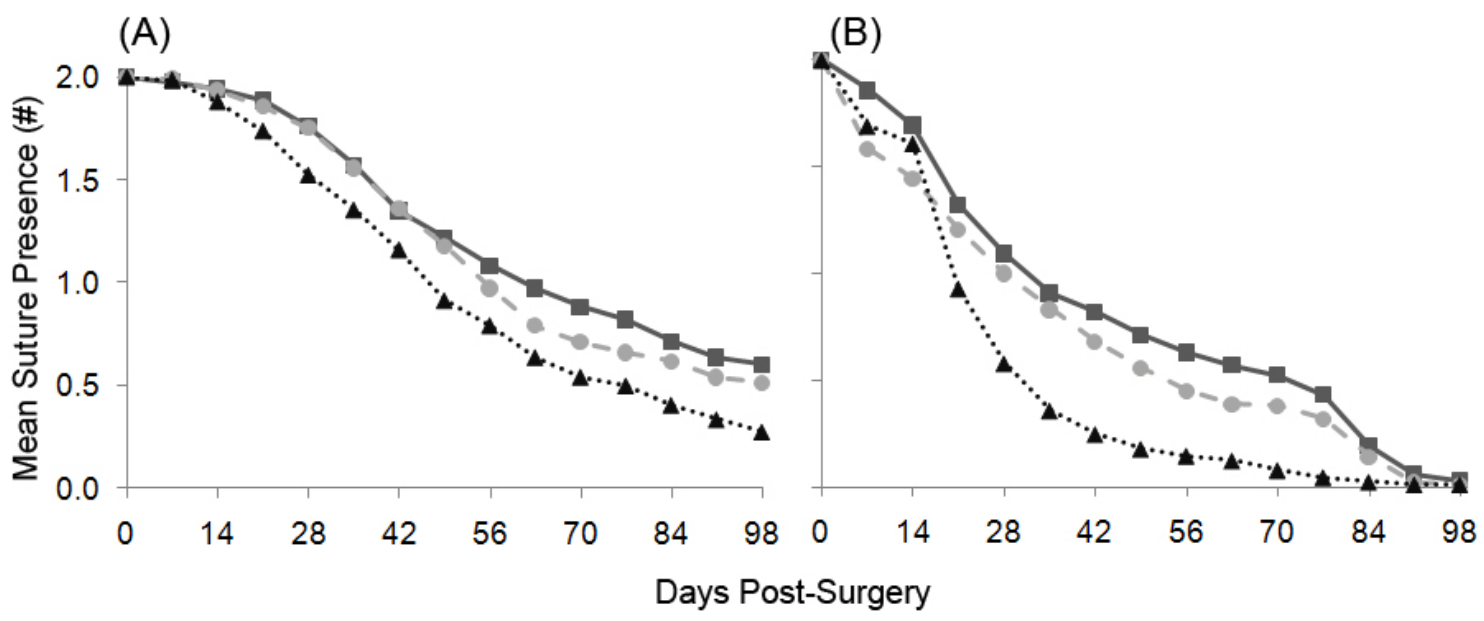

Figure 3.5. Mean suture presence among juvenile Chinook salmon implanted with an acoustic transmitter and PIT tag through an incision on the linea alba (--) ), a muscle-cutting $\left({ }^{-}-\right)$ incision, or a muscle-sparing $(\cdot * \cdot)$ incision and held at $12^{\circ} \mathrm{C}(\mathrm{A})$ or $20^{\circ} \mathrm{C}(\mathrm{B})$

\subsection{Mortality and Growth}

Mortality of surgically implanted fish was generally low (Table 3.1). There were no mortalities among fish held at $12^{\circ} \mathrm{C}$. Although mortality among fish held at $20^{\circ} \mathrm{C}$ ranged from $11 \%$ to $20 \%$, there was no significant difference $(P=0.181)$ among groups with different incision locations.

During most of the study period (all but day 91 for fish held at $12^{\circ} \mathrm{C}$ ), there was no significant difference $(P>0.05)$ in growth among incision location groups held at both temperatures. On day 91, fish with muscle-cutting incisions at $12^{\circ} \mathrm{C}$ had significantly higher growth $(P=0.02)$ than fish with incisions on the linea alba. However, on this day, growth among fish with muscle-cutting incisions and incisions on the linea alba was not significantly different $(P=0.69)$ from fish with muscle-sparing incisions.

Table 3.1. Instantaneous growth rate (IGR), cumulative mortality, and transmitter loss over 98 days among juvenile Chinook salmon implanted with an acoustic transmitter and PIT tag through an incision on the linea alba, a muscle-cutting incision, or a muscle-sparing incision

\begin{tabular}{cccccc}
\hline $\begin{array}{c}\text { Temp. } \\
\left({ }^{\circ} \mathrm{C}\right)\end{array}$ & Treatment & $N$ & $\begin{array}{c}\text { Growth } \\
\text { (IGR) }\end{array}$ & $\begin{array}{c}\text { Mortality } \\
\text { (cumulative \%) }\end{array}$ & $\begin{array}{c}\text { Transmitter loss } \\
\text { (cumulative \%) }\end{array}$ \\
\hline \multirow{2}{*}{$\begin{array}{c}\text { Linea alba } \\
\text { Muscle-cutting }\end{array}$} & 156 & 0.09 & $0(0 \%)$ & $16(13 \%)$ \\
& Muscle-sparing & 158 & 0.10 & $0(0 \%)$ & $1(1 \%)$ \\
& Control & 155 & 0.09 & $0(0 \%)$ & -- \\
& & & & $0(0 \%)$ & $9(9 \%)$ \\
& Linea alba & 156 & 0.20 & $20(20 \%)$ & $7(7 \%)$ \\
& Muscle-cutting & 156 & 0.19 & $17(16 \%)$ & $2(3 \%)$ \\
& Muscle-sparing & 121 & 0.20 & $11(13 \%)$ & -- \\
& Control & 157 & 0.21 & $12(11 \%)$ & \\
\hline
\end{tabular}




\subsection{Histology}

Healing of incisions followed a similar progression among fish held at both temperatures, with the various responses occurring more quickly at $20^{\circ} \mathrm{C}$. The inflammatory response in the epidermis, dermis, and musculature generally peaked on day 21 among fish held at $12^{\circ} \mathrm{C}$ compared to day 14 among fish held at $20^{\circ} \mathrm{C}$. The amount of fibrotic tissue within the incision peaked on day 21 among fish held at $12^{\circ} \mathrm{C}$ compared to day 10 among fish held at $20^{\circ} \mathrm{C}$. Because no difference in the progression of healing occurred among fish held at either temperature, the following results are presented only for fish held at $12^{\circ} \mathrm{C}$.

Healing progressed in a similar manner among the three incision types during the first 14 days among fish held at $12^{\circ} \mathrm{C}$ (Figure 3.6). Thickening of the epidermis occurred as epithelial cells proliferated and migrated around the cut edges of the incision, covering any exposed muscle or viscera. On average, $75 \%$ of all incision types either lacked fusion of the dermis, epidermis, and musculature from days 3 through 14 , or were so weakly fused that the layers broke apart when transects across the incisions were cut prior to embedding and staining (Figure 3.6). Neovascularization within the incision was present as early as day 3 in all incision types and increased steadily during the first 14 days. Moderate amounts of inflammatory cells were present in the serosal surface and musculature by day 3 , and were noted in the dermis and epidermis on day 10. Muscle-cutting and muscle-sparing incisions had greater numbers of inflammatory cells in the serosal surface and musculature than incisions on the linea alba. The dermis and the epidermis of both edges of $92 \%$ of incisions on the linea alba were folded inward. In contrast, $54 \%$ of muscle-cutting and $42 \%$ of muscle-sparing incisions had at least one or both edges of the incision folded inward.

By day 21, the most notable difference among incision types of fish held at $12^{\circ} \mathrm{C}$ was the amount of fibrotic tissue present in the incision (Figure 3.7). Muscle-cutting and muscle-sparing incisions had much greater amounts of fibrotic tissue within the incision compared to incisions on the linea alba. The dermis remained ingrown on both edges of the majority (83\%) of incisions on the linea alba, compared to ingrowth of one or both sides of muscle-cutting (50\%) and muscle-sparing (17\%) incisions. Inflammatory cells were observed at their highest levels in all three incision types on day 21, with the amounts being similar. Tissue layers on either side of the incision were misaligned in the majority (77\% on average) of all incision types. Healing was still in progress by day 49 for all incision types, and the amount of fibrotic tissue and inflammatory cells decreased. However, muscle-cutting and muscle-sparing incisions still had greater amounts of fibrotic tissue present in the incision compared to incisions on the linea alba.

Most of the incisions of fish held at $12^{\circ} \mathrm{C}$ were fully healed by day 98 (Figure 3.8). Epidermal and dermal layers were fused, and muscle tissue had regenerated, where the incision had been made. Small pieces of fibrotic tissue (fibrotic tags) on the serosal surface were present in varying quantities on all three incision types.

Some anomalous situations existed where some incisions of fish held at $12^{\circ} \mathrm{C}$ were not healed by day 98. An incision on the linea alba (Figure 3.9) failed to close, with no regrowth of muscle and large amounts of fibrous granulation tissue between the incision edges. The epidermis was hyperplasic (excessively proliferating) and appeared chaotic. An image of the outside of the incision on day 98 revealed a large mat of Saprolegnia sp. covering the incision. One muscle-sparing incision (Figure 3.10) had severe misalignment of incision edges, with extensive fibrosis throughout the incision. The 
epidermis was hyperplasic, and the dermis was protruding into the incision area. An image of the outside of the incision on day 0 showed the edges of the incision were overlapping (Figure 3.10(A)). The edges of the incision were together by day 49 but indented (Figure 3.10(B)). Although the surface of the incision appeared to be cosmetically resolved by day 98 , histology revealed the underlying muscle and tissue layers were not fully healed (Figure 3.10(C)). 


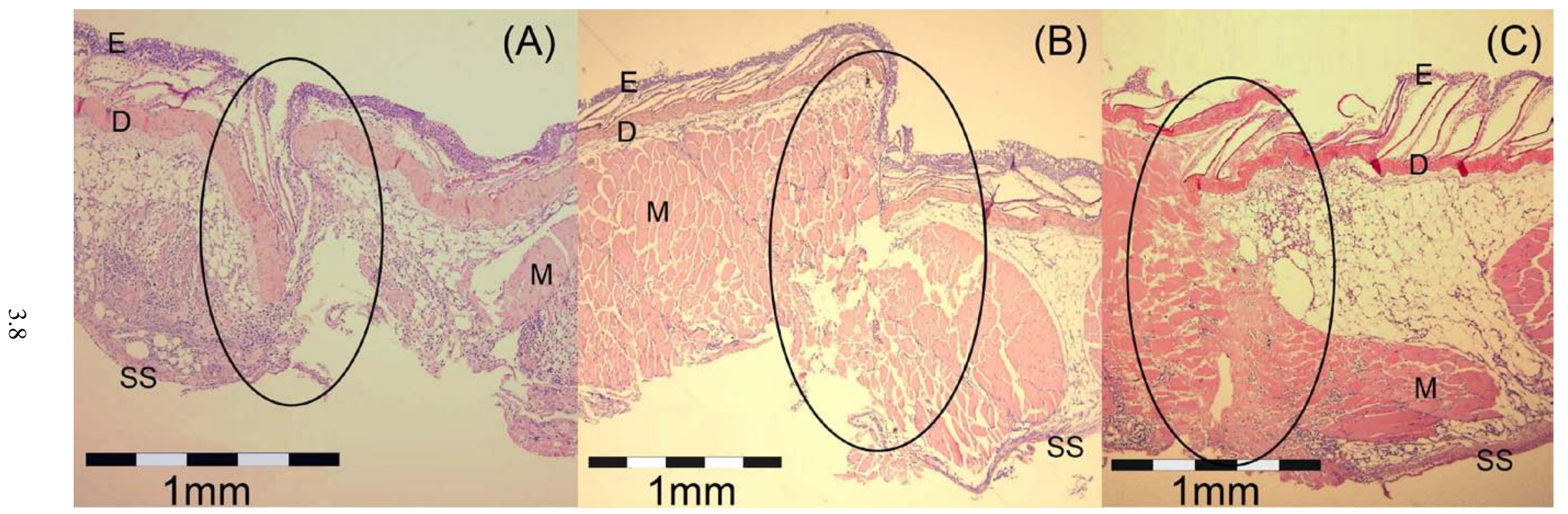

Figure 3.6. Transverse section of an incision on the linea alba (A), a muscle-cutting incision (B), and a muscle-sparing incision (C) on day 14. Incisions (within black ovals) are healing in a similar manner. The epidermis (E) and dermis (D) are not aligned, and the dermis lacks fusion. Number of inflammatory cells was greater in the serosal surface (SS) and musculature (M) of muscle-cutting and musclesparing incisions than incisions on the linea alba. 


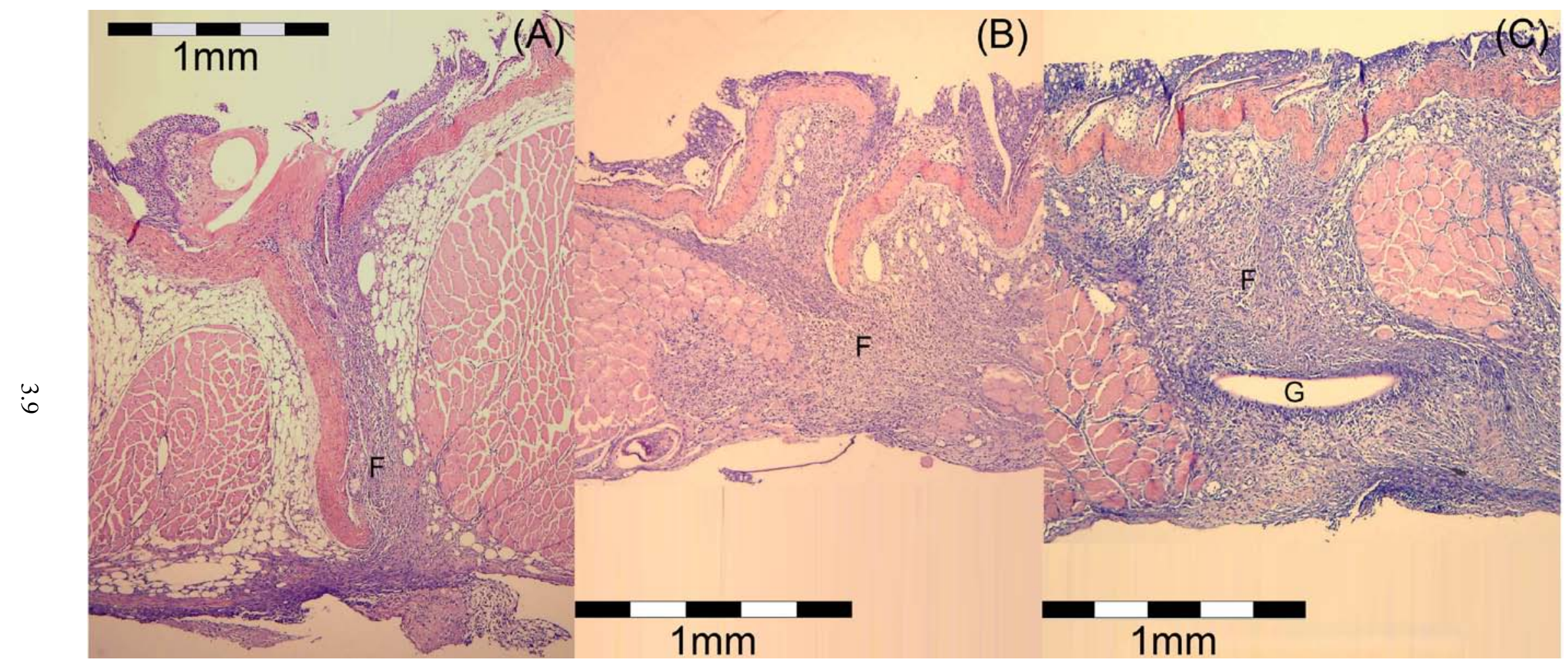

Figure 3.7. Transverse section of an incision on the linea alba (A), a muscle-cutting incision (B), and a muscle-sparing incision (C) on day 21. Fibrous granulation tissue $(\mathrm{F})$ is present in greater quantities in the muscle-cutting and muscle-sparing incisions than in the incision on the linea alba. The gap $(\mathrm{G})$ in the fibrous granulation tissue of the muscle-sparing incision is an artifact from processing. 


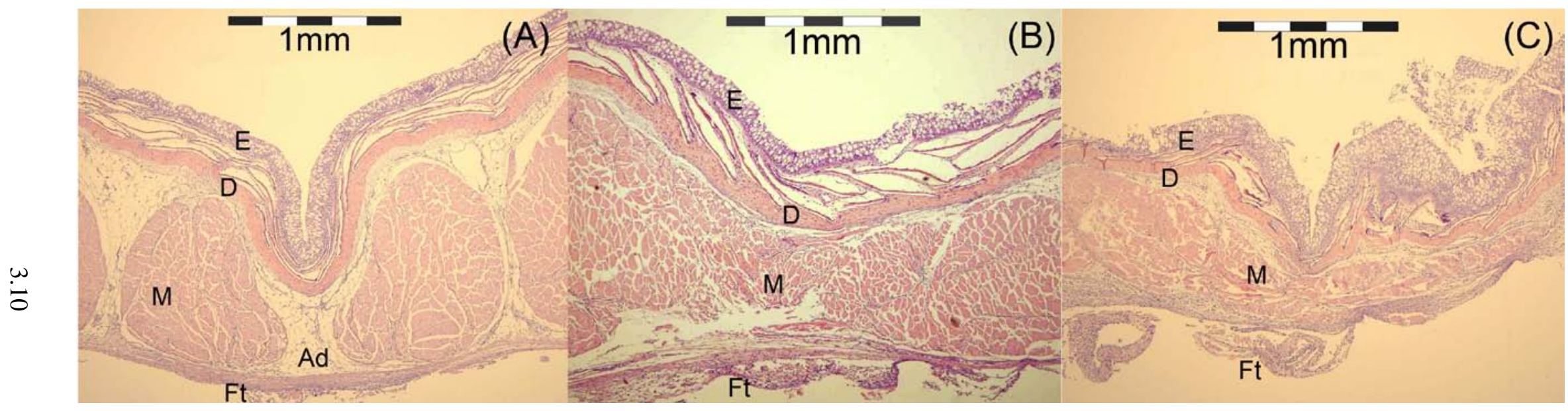

Figure 3.8. Transverse section of the three incision locations on day 98. The incision in the adipose tissue (Ad) of the linea alba (A) is completely healed, as are the incisions in the musculature (M) of the muscle-cutting incision (B) and muscle-sparing incision (C). The epidermis (E) and dermis (D) are continuous and fused, and the fibrous granulation tissue has been replaced with normal tissue. Fibrotic tags (Ft) were present on the serosal surface of all three incision locations. 


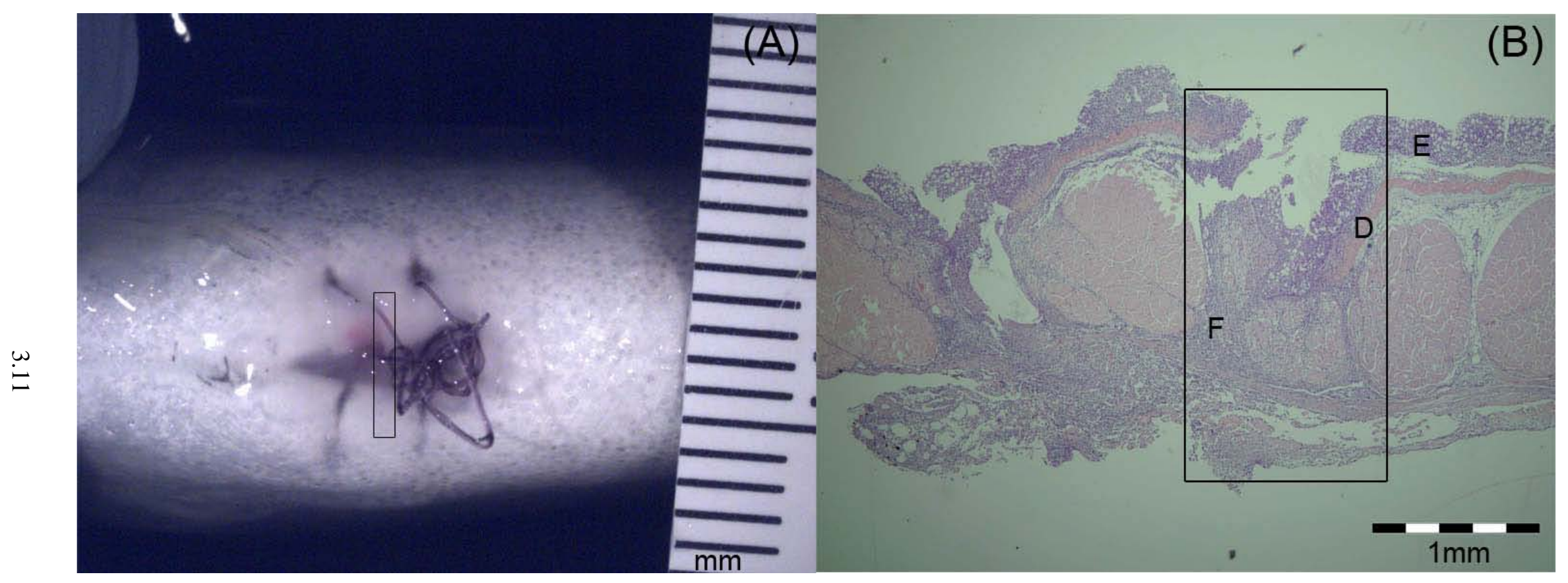

Figure 3.9. Anomalous healing of an incision on the linea alba on day 98. Externally (A) the incision is covered with Saprolegnia sp. The rectangle in image (A) shows the cross section of the incision that was processed for histology. The transverse view of the cross section (B) shows a thickened epidermis (E), discontinuous dermis (D), and large amounts of fibrotic tissue (F) between the edges of the incision. 


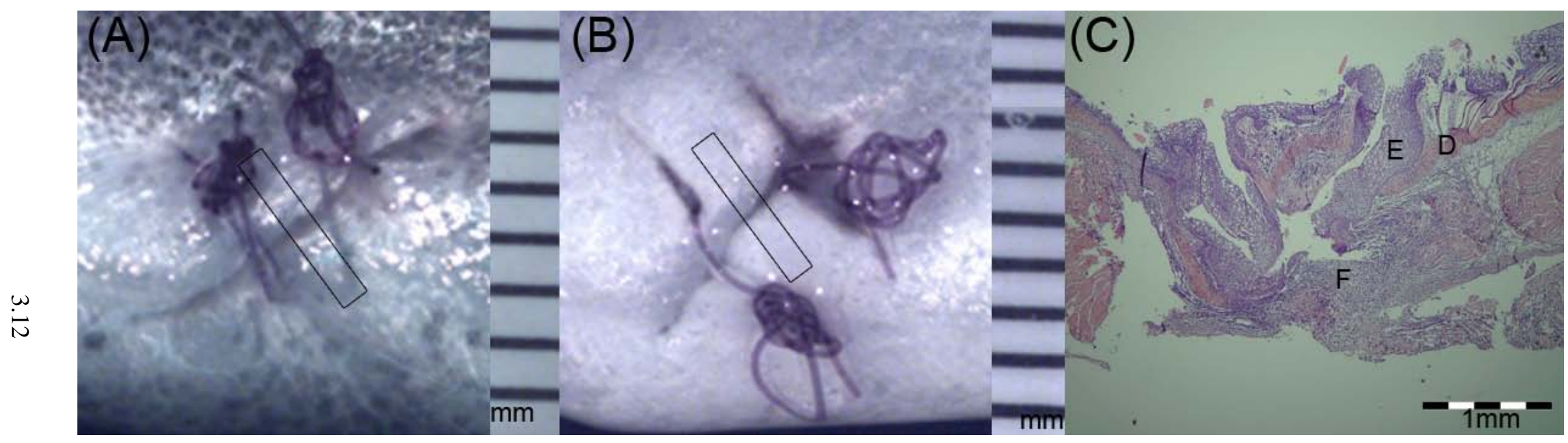

Figure 3.10. Anomalous healing of a muscle-sparing incision. Externally on day 0 (A), the incision edges were overlapping. By day 49 (B), the incision edges were together but remained indented. The rectangle in images (A) and (B) shows the cross section of the incision that was processed for histology. The transverse view of the cross section (C) on day 98 shows a thickened epidermis (E), discontinuous dermis (D), and large amounts of fibrotic tissue (F) between the edges of the incision. 


\subsection{Discussion}

\subsection{Transmitter Loss}

Although transmitter loss was most common among fish with incisions on the linea alba later in the study, there was no significant difference during the first 28 days of both temperature treatments. However, other researchers did not observe as much tag expulsion through the linea alba. A separate study on various suture knot patterns was conducted on similarly sized juvenile Chinook salmon implanted with the same JSATS transmitter and a PIT tag through an incision on the linea alba in 2009 (K. A. Deters, PNNL, personal communication, 2010). Throughout that 28-day study, only 1 of 225 acoustic transmitters was lost from fish held at $17^{\circ} \mathrm{C}$; in addition, only 2 PIT tags and no acoustic transmitters were lost from 262 fish held at $12^{\circ} \mathrm{C}$. In the study reported here, the transmitter loss from incisions on the linea alba during the first 28 days was very small (4\%) and was not significantly higher than loss from muscle-cutting and muscle-sparing incisions.

Transmitter loss was highest among fish with incisions on the linea alba by day 98 for fish held at $12^{\circ} \mathrm{C}$ and may have been related to how the incisions were healing. Histological results showed that as incisions on the linea alba were healing, the edges curled inward and were connected only weakly with a thin layer of epithelial cells, as described by Phromsuthirak (1977). The weight of the transmitter on the incision may have caused the sutures to fail (Schramm and Black 1984) and likely overcame the weak bond between the incision edges, causing the incision to dehisce and the transmitter to be lost through the incision (i.e., gravity; Marty and Summerfelt 1986; Sakaris et al. 2005). All incisions healed faster at $20^{\circ} \mathrm{C}$, and it is possible that the strength of the incision increased quickly enough to support the transmitter, thus preventing the loss of more transmitters. Therefore, the results of this study suggest that the odds of losing a transmitter through an incision on the linea alba may decrease as temperature increases and the rate of healing increases.

\subsection{Healing}

It is clear that incisions on the linea alba had better initial apposition and less openness than musclecutting and muscle-sparing incisions during the first 14 days at $12^{\circ} \mathrm{C}$ or $20^{\circ} \mathrm{C}$. This difference was likely related to natural resting tension in the myomeres. When human muscle is cut, it retracts similar to a cut rubber band (Dederich 1963) because of its viscoelastic properties (Heidemann et al. 1999; Long et al. 2002). We observed that when the lateral muscles of an anaesthetized fish were cut with the musclecutting incision, the resting tension caused the edges of the incision to retract and gape open. Retraction made the tissue edges extremely difficult to appose, and muscle-cutting incisions consequently had the greatest amount of open area among incision types. Additionally, when the fish recovered from anesthesia and began swimming, it is probable that the active contraction of the muscles continued to pull apart the edges of the muscle-cutting incision, further contributing to the greater openness observed in muscle-cutting incisions. The bending of the fish's body during swimming may have caused musclesparing incisions to exhibit greater openness relative to incisions on the linea alba. Openness and apposition in muscle-cutting and muscle-sparing incisions may improve with better surgical techniques, but the natural tension in muscle tissue and the fish's swimming movements likely will limit these improvements. 
The way in which erythema was measured in this study may have made it a poor metric to relate to healing. Early in the study (days 0-14), incisions on the linea alba had less erythema than the other two incision types at $12^{\circ} \mathrm{C}$, but the opposite was true at $20^{\circ} \mathrm{C}$. These results were somewhat misleading and were related to how erythema was recorded. Erythema was noted when it was visible against the scales and integument. However, many muscle-cutting and some muscle-sparing incisions at $20^{\circ} \mathrm{C}$ expelled sutures that tore scales and integument away from the incision edges, making it difficult to observe erythema. Furthermore, the importance of erythema was uncertain because the mechanism producing the erythema was not identifiable by gross examination. Our histology results indicated that substantial inflammation of the tissues could occur without any visible erythema. Erythema could also be present without any inflammation in the underlying tissues. Without knowing the mechanism of how erythema was produced, and without tracking changes in erythema over time for individual fish, it did not appear to be a useful predictor in the final outcome of the healing of the incision. Future studies should consider using other means (such as histology) to accurately assess wound healing, in addition to tracking changes in erythema, changes in wound area or perimeter, color, signs of infection, and wound closure (Lazarus et al. 1994; Franz et al. 2008).

The results of this laboratory study showed that incisions on the linea alba had less evidence of healing by secondary intention and much less open area, both of which could prove beneficial to the health of the fish. Less openness of incisions on the linea alba may benefit the fish by requiring less energy to heal and decreasing the chance for pathogens to enter. When incisions are not apposed to heal by primary intention (edges of the incision are first aligned and secured together with sutures), they take longer to heal by a process called secondary intention (Barbul 2005; McCallum et al. 2007). During secondary intention, a gap exists between the incision edges and must first be filled with fibrous granulation tissue, healing from the bottom up (Barbul 2005). The fibrous granulation tissue eventually contracts, pulling the edges of the incision into apposition. Both muscle-sparing and muscle-cutting incisions appeared to heal by secondary intention because histological examination revealed that both contained greater amounts of fibrous tissue in the musculature than incisions within the adipose and connective tissue on the linea alba. Therefore, muscle-sparing and muscle-cutting incisions likely required more energy to heal (Barbul 2005). Additionally, the openness in muscle-cutting and musclesparing incisions will likely lead to a larger pathway for pathogens to enter (Svendsen and Bogwald 1997; Noga 2000) and may interfere with efficient osmoregulation (Lunder 1992).

\subsection{Suture Presence}

Sutures were lost faster from muscle-sparing incisions, most likely due to the angle of the sutures on the body. As the fish swam, the force of the water on the sutures of muscle-sparing incisions may have pushed the sutures toward the incision, enabling them to be expelled more easily. In contrast, on musclecutting incisions and incisions on the linea alba, the force of the water pushed the sutures parallel to the incision, allowing the suture to remain in the body wall longer.

Suture loss from all incisions was higher in the warmer $\left(20^{\circ} \mathrm{C}\right)$ group than in the colder $\left(12^{\circ} \mathrm{C}\right)$ group. Similarly, Walsh et al. (2000) found more than $50 \%$ of the absorbable monofilament sutures implanted in hybrid striped bass were expelled 60 days post-surgery at warm temperatures (mean $25.5^{\circ} \mathrm{C}$ ), but that less than $25 \%$ were expelled at cold temperatures (mean $15^{\circ} \mathrm{C}$ ), even at 120 days post-surgery. Deters et al. (2010) also found suture loss to be higher (36\%) in juvenile Chinook salmon held at $17^{\circ} \mathrm{C}$ compared to suture loss $(18 \%)$ in fish held at $12^{\circ} \mathrm{C}$ after 14 days. 
If suture material persists in fish tissue, the risk of infection or irritation from the suture rubbing back and forth against the tissue may increase over time. Many studies have sought to determine the best suture material for fish surgeries and commonly report that monofilament sutures elicit less tissue reaction than other materials such as silk, catgut, or nylon (Kaseloo et al. 1992; Gilliland 1994; Wagner et al. 2000; Hurty et al. 2002; Mulcahy 2003; Harms 2005; Deters et al. 2010). However, the minimal tissue reaction may be why monofilament sutures persist for so long, and the constant rubbing of suture material against the fish's tissue may elicit an adverse reaction. Caputo et al. (2009) reported absorbable monofilament sutures were retained in largemouth bass from 362 to 733 days post-surgery, and there were redness and signs of infection around the sutures. Roberts et al. (1973) reported that external tags, which were attached to the dorsal musculature of ocean-going Atlantic salmon with monofilament nylon suture, remained attached for more than two years. Histological analysis on the dorsal musculature showed much greater necrosis and bacterial presence around suture material connected to a trailing tag that could move than an embedded tag that could not move (Roberts et al. 1973). Irritation around monofilament suture decreases or disappears once the suture is lost (Walsh et al. 2000) or cannot move (Roberts et al. 1973). Therefore, although impractical in most field studies, it would seem ideal to use monofilament sutures to close the incision, removing the sutures once the incision heals, and thus avoid any negative effects (i.e., infection or decreases in growth) that may come from the sutures rubbing against fish tissue.

\subsection{Mortality}

Mortality did not differ among incision types in the controlled laboratory setting. However, mortality or adverse effects from incision openness may increase in a field setting where bacterial loads and environmental factors vary. 


\subsection{Conclusions and Recommendations}

This study found the incision on the linea alba to be a better choice than muscle-cutting and musclesparing incisions for studies up to 28 days in length. Transmitter retention was similar among the three incision locations during the first 28 days when fish were held at $12^{\circ} \mathrm{C}$ or $20^{\circ} \mathrm{C}$. Incisions on the linea alba were much less open than the muscle-cutting and muscle-sparing incisions, suggesting a decreased risk of invading pathogens. Apposition of incisions during the first 14 days at both temperatures was better for incisions on the linea alba than muscle-cutting and muscle-sparing incisions because the muscle retracted when cut and was more difficult to appose. The results from histology confirmed that incisions on the linea alba were healing with much less fibrotic tissue than were the muscle-cutting or musclesparing incisions, suggesting more incisions were healing by primary rather than secondary intention. Incision closure (external healing) was better for incisions on the linea alba than muscle-cutting and muscle-sparing incisions on 28 days at $12^{\circ} \mathrm{C}$ and 21 days at $20^{\circ} \mathrm{C}$. Suture presence was higher for incisions on the linea alba than muscle-sparing incisions by day 28 at both temperatures.

Several areas of study were identified for future research. One would be to examine possible links between suture presence and decreased growth over the long term. A second study could quantify how various suture bites and varying amounts of tension different surgeons place on the suture knots influence healing rates and transmitter expulsion. 


\subsection{References}

Adams NS, DW Rondorf, SD Evans, JE Kelly, and RW Perry. 1998. Effects of surgically and gastrically implanted radio transmitters on swimming performance and predator avoidance of juvenile Chinook salmon (Oncorhynchus tshawytscha). Canadian Journal of Fisheries and Aquatic Sciences 55:781-787.

Anderson CD and RJ Roberts. 1975. A comparison of the effects of temperature on wound healing in a tropical and a temperate teleost. Journal of Fish Biology 7:173-182.

Barbul A. 2005. Wound healing. In Schwartz's Principles of Surgery, 8th edition, FC Brunicardi, DK Andersen, TR Billiar, DL Dunn, JG Hunter, and RE Pollock (eds), pp. 223-248. McGraw-Hill, New York.

Bly JE and LW Clem. 1992. Temperature and teleost immune functions. Fish \&Shellfish Immunology 2:159-171.

Bunnell DB and JJ Iseley. 1999. Influence of temperature on mortality and retention of simulated transmitters in rainbow trout. North American Journal of Fisheries Management 19:152-154.

Bunnell DB, JJ Iseley, KH Burrell, and DH Van Lear . 1998. Diel Movement of brown trout in a southern Appalachian river. Transactions of the American Fisheries Society 127:630-636.

Caputo M, CM O’Connor, CT Hasler, KC Hanson, and SJ Cooke. 2009. Long-term effects of surgically implanted telemetry tags on the nutritional physiology and condition of wild freshwater fish. Diseases of Aquatic Organisms 84:35-41.

Cobb EW. 1933. Results of trout tagging to determine migrations and results from plants made. Transactions of the American Fisheries Society 63(1):308-318.

Cunha da Silva JRM, EL Cooper, IL Sinhorini, JCS Borges, BE Jensch-Junior, LR Porto-Neto, FJ Hernandez-Blazquez, BC Vellutini, LN Pressinotti, and FA Costa-Pinto. 2005. Microscopical study of experimental wound healing in Notothenia coriiceps (Cabecuda) at $0^{\circ} \mathrm{C}$. Cell \& Tissue Research 321:401-410.

Dederich R. 1963. Plastic treatment of the muscles and bone in amputation and surgery. The Journal of Bone and Joint Surgery 45B(1):60-66.

Deters KA, RS Brown, KM Carter, JW Boyd, MB Eppard, and AG Seaburg. 2010. Performance assessment of suture type, water temperature, and surgeon skill in juvenile Chinook salmon surgically implanted with acoustic transmitters. Transactions of the American Fisheries Society 139:888-899. DOI: 10.1577/T09-043.1.

Dieterman DJ and RJH Hoxmeier. 2009. Instream evaluation of passive integrated transponder retention in brook trout and brown trout: effects of season, anatomical placement, and fish length. North American Journal of Fisheries Management 29:109-115. 
Elston R, J Colt, S Abernethy, and W Maslen. 1997. Gas bubble reabsorption in Chinook salmon: pressurization effects. Journal of Aquatic Animal Health 9:317-321.

Euteneuer U and M Schliwa. 1984. Persistent directional motility of cells and cytoplasmic fragments in the absence of microtubules. Nature 310:58-61.

Franz MG, MC Robson, DL Steed, A Barbul, H Brem, DM Cooper, D Leaper, SM Milner, WG Payne, TL Wachtel, and L Wiersem-Bryant. 2008. Guidelines to aid healing of acute wounds by decreasing impediments of healing. Wound Repair and Regeneration 16:723-748.

Gilliland ER. 1994. Comparison of absorbable sutures used in largemouth bass liver biopsy surgery. Progressive Fish-Culturist 56:60-61.

Harms CA. 2005. Surgery in fish research: common procedures and postoperative care. Laboratory Animals 34(1):28-34.

Hart LG and RC Summerfelt. 1975. Surgical procedures for implanting ultrasonic transmitters into flathead catfish (Pylodictis olivaris). Transactions of the American Fisheries Society 104:56-59.

Heidemann SR, S Kaech, RE Buxbaum, and A Matus. 1999. Direct observations of the mechanical behaviors of the cytoskeleton in living fibroblasts. The Journal of Cell Biology 145(1):109-122.

Hurty CA, DC Brazic, JM Law, K Sakamoto, and GA Lewbart. 2002. Evaluation of the tissue reactions in the skin and body wall of koi (Cyprinus carpio) to five suture materials. Veterinary Record 151:324328.

Isely JJ and TB Grabowski. 2007. Age and growth. In Analysis and Interpretation of Freshwater Fisheries Data, CS Guy and ML Brown (eds), Chapter 5, pp. 187-228. American Fisheries Society, Bethesda, Maryland.

Kaseloo PA, AH Weatherly, J Lotimer, and MD Farina. 1992. A biotelemetry system recording fish activity. Journal of Fish Biology 40:165-179.

Knights BC and BA Lasee. 1996. Effects of implanted transmitters on adult bluegills at two temperatures. Transactions of the American Fisheries Society 125:440-449.

Lazarus GS, DM Cooper, DR Knighton, DJ Margolis, RE Pecoraro, G Rodeheaver, and MC Robson. 1994. Definitions and guidelines for assessment of wounds and evaluation of healing. Archives of Dermatology 130:489-493.

Le Morvan C, D Troutaud, and P Deschaux. 1998. Differential effect of temperature on specific and nonspecific immune defenses in fish. The Journal of Experimental Biology 201:165-168.

Logan VH and PH Odense. 1974. The integument of the ocean sunfish (Mola mola L.) (Plectognathi) with observations on the lesions from two ectoparasites, Capsala tnartinieri (Trematoda) and Philorthagoriscus serratus (Copepoda). Canadian Journal of Zoology 52:1039-1045. 
Long JH, B Adcock, and RG Root. 2002. Force transmission via axial tendons in undulating fish: a dynamic analysis. Comparative Biochemistry and Physiology Part A 133:911-929.

Lowartz SM, DL Holmberg, HW Ferguson, and FWH Beamish. 1999. Healing of abdominal incisions in sea lamprey larvae: a comparison of three wound-closure techniques. Journal of Fish Biology 54:616626.

Lucas MC. 1989. Effects of implanted dummy transmitters on mortality, growth and tissue reaction in rainbow trout, Salmo gairdneri Richardson. Journal of Fish Biology 35:577-587.

Lunder T. 1992. 'Winter ulcer' in Atlantic salmon. A study of pathologica1 changes, transmissibility, bacterial isolates. Doctoral dissertation, The Norwegian College of Veterinary Medicine, Oslo.

Marty GD and RC Summerfelt. 1986. Pathways and mechanisms for expulsion of surgically implanted dummy transmitters from channel catfish. Transactions of the American Fisheries Society 115:577-589.

McCallum I, PM King, J Bruce, and A Al-Khamis. 2007. Healing by primary versus secondary intention after surgical treatment for pilonidal sinus. Cochrane Database of Systematic Reviews 4.

Mulcahy DM. 2003. Surgical implantation of transmitters into fish. ILAR Journal 44:295-306.

Nikoskelainen S, G Bylund, and E-M Lilius. 2004. Effect of environmental temperature on rainbow trout (Oncorhynchus mykiss) innate immunity. Developmental and Comparative Immunology 28:581592.

Noga EJ. 2000. Fish Disease: Diagnosis and Treatment. Blackwell Publishing Company, Ames, Iowa.

Pautzke CF and RC Meigs. 1941. Studies on the life history of the Puget Sound steelhead trout (Salmo gairdnerii). Transactions of the American Fisheries Society 70:209-220.

Peven C, A Giorgi, J Skalski, M Langeslay, A Grassell, S Smith, T Counihan, R Perry, and S Bickford. 2005. Guidelines and suggested protocols for conducting, analyzing, and reporting juvenile salmonid survival studies in the Columbia River Basin. University of Washington School of Aquatic \& Fishery Sciences, Columbia Basin Research, Seattle.

Phromsuthirak P. 1977. Electron microscopy of wound healing in the skin of Gasterosteus aculeatus. Journal of Fish Biology 11:193-206.

Radice GP. 1980a. The spreading of epithelial cells during wound closure in Xenopus larvae. Developmental Biology 76:26-46.

Radice GP. 1980b. Locomotion and cell-substratum contacts of Xenopus epidermal cells in vitro and in situ. Journal of Cell Science 44:201-223.

Ream RA, JA Theriot, and GN Somero. 2003. Influences of thermal acclimation and acute temperature change on the motility of epithelial wound-healing cells (keratocytes) of tropical, temperate, and Antarctic fish. The Journal of Experimental Biology 206:4539-4551. 
Richards RH and AD Pickering. 1979. Changes in serum parameters of Saprolegnia-infected brown trout, Salmo trutta L. Journal of Fish Diseases 2:197-206.

Roberts RJ (ed). 1989. Fish Pathology. 2nd edition. Bailliere-Tindall, London.

Roberts JR, A McQueen, WM Shearer, and H Young. 1973. The histopathology of salmon tagging II. The chronic tagging lesion in returning adult fish. Journal of Fish Biology 5:615-619.

Sakaris PC, RV Jesien, and AE Pinkney. 2005. Retention of surgically implanted ultrasonic transmitters in the brown bullhead catfish. North American Journal of Fisheries Management 25:822-826.

Sen CK. 2009. Wound healing essentials: let there be oxygen. Wound Repair and Regeneration 17:1-18.

Shephard KL. 1994. Functions for fish mucus. Reviews in Fish Biology and Fisheries 4:401-429.

Schramm HL and DJ Black. 1984. Anesthesia and surgical procedures for implanting radiotransmitters into grass carp. Progressive Fish-Culturist 46:185-190.

Smith SG, WD Muir, EE Hockersmith, RW Zabel, RJ Graves, CV Ross, WP Connor, and BD Arnsberg. 2003. Influence of river conditions on survival and travel time of Snake River subyearling fall Chinook salmon. North American Journal of Fisheries Management 23: 939-961.

Snedecor GW and WG Cochran. 1989. Statistical Methods. 8th edition. Iowa State Press, Ames.

Summerfelt RC and LS Smith. 1990. Anesthesia, surgery, and related techniques. In Methods for Fish Biology, CB Schreck and PB Moyle (eds), pp. 171-190. American Fisheries Society, Bethesda, Maryland.

Svendsen YS and J Bogwald. 1997. Influence of artificial wound and non-intact mucus layer on mortality of Atlantic salmon (Salmo salar L.) following a bath challenge with Vibrio anguillarum and Aeromonas salmonicida. Fish and Shellfish Immunology 7:317-325.

Wagner GN and ED Stevens. 2000. Effects of different surgical techniques: suture material and location of incision site on the behavior of rainbow trout (Oncorhynchus mykiss). Marine and Freshwater Behaviour and Physiology 33:103-114.

Wagner GN, ED Stevens, and P Byrne. 2000. Effects of suture type and patterns on surgical wound healing in rainbow trout. Transactions of the American Fisheries Society 129(5):1196-1205.

Walsh MG, KA Bjorgo, and JJ Isely. 2000. Effects of implantation method and temperature on mortality and loss of simulated transmitters in hybrid striped bass. Transactions of the American Fisheries Society 129:539-544.

Winter J. 1996. Advances in underwater biotelemetry. In Fisheries Techniques, 2nd edition, BR Murphy and DW Willis (eds), pp.555-590. American Fisheries Society, Bethesda, Maryland. 
Wynne R, M Botti, H Stedman, L Holsworth, M Harinos, O Flavell, and C Manterfield. 2004. Effect of three wound dressings on infection, healing comfort, and cost in patients with sternotomy wounds: a randomized trial. Chest 125:43-49. 
Appendix A

\section{Detailed Statistical Analysis}




\section{Appendix A}

\section{Detailed Statistical Analysis}

This appendix provides more detail on the statistical analysis performed on the influence of incision location on transmitter loss, healing, incision lengths, suture retention, and growth of juvenile Chinook salmon. 
Table A.1. ANOVA on mean open area among incision locations by week at $12^{\circ} \mathrm{C}$ and $20^{\circ} \mathrm{C}$.

\begin{tabular}{|c|c|c|c|c|c|c|c|c|}
\hline \multirow[b]{2}{*}{ Temp. } & \multirow[b]{2}{*}{ Location } & \multicolumn{7}{|c|}{ Day } \\
\hline & & 7 & 14 & 21 & 28 & 35 & 42 & 49 \\
\hline \multirow{3}{*}{$\stackrel{\cup}{\stackrel{\cup}{\nearrow}}$} & Linea alba & $0.0 \pm 0.0 a$ & $0.3 \pm 0.1 a$ & $0.4 \pm 0.1 a$ & $0.4 \pm 0.1 a$ & $0.7 \pm 0.2 a$ & $0.8 \pm 0.2 a$ & $0.8 \pm 0.2 a$ \\
\hline & Muscle-cutting & $1.7 \pm 0.1 b$ & $2.7 \pm 0.1 b$ & $1.2 \pm 0.1 b$ & $0.7 \pm 0.1 a, b$ & $0.8 \pm 0.1 a$ & $0.5 \pm 0.2 a$ & $0.3 \pm 0.1 a, b$ \\
\hline & Muscle-sparing & $0.3 \pm 0.0 c$ & $1.9 \pm 0.1 c$ & $1.4 \pm 0.2 b$ & $0.7 \pm 0.1 b$ & $0.5 \pm 0.1 a$ & $0.3 \pm 0.1 a$ & $0.2 \pm 0.1 b$ \\
\hline \multirow{4}{*}{$\begin{array}{l}\text { Uे } \\
\stackrel{\sim}{\circ}\end{array}$} & Linea alba & $0.5 \pm 0.1 a$ & $1.0 \pm 0.2 a$ & $1.3 \pm 0.3 a$ & $0.4 \pm 0.1 a$ & $0.2 \pm 0.1 a$ & $0.0 \pm 0.0 a$ & $0.0 \pm 0.0 a$ \\
\hline & Muscle-cutting & $5.7 \pm 0.4 b$ & $2.5 \pm 0.3 b$ & $1.9 \pm 0.2 a$ & $0.2 \pm 0.1 a$ & $0.1 \pm 0.1 a$ & $0.0 \pm 0.0 a$ & $0.0 \pm 0.0 a$ \\
\hline & Muscle-sparing & $5.4 \pm 0.7 b$ & $2.5 \pm 0.4 b$ & $2.5 \pm 0.4 b$ & $0.4 \pm 0.1 a$ & $0.1 \pm 0.1 a$ & $0.0 \pm 0.0 a$ & $0.0 \pm 0.0 a$ \\
\hline & & 56 & 63 & 70 & 77 & 84 & 91 & 98 \\
\hline \multirow{3}{*}{$\begin{array}{l}\text { ○े } \\
\stackrel{\sim}{-}\end{array}$} & Linea alba & $1.0 \pm 0.4 a$ & $0.3 \pm 0.1 a$ & $0.3 \pm 0.2 a$ & $0.5 \pm 0.2 a$ & $0.3 \pm 0.1 a$ & $0.3 \pm 0.1 a$ & $0.3 \pm 0.1 a$ \\
\hline & Muscle-cutting & $0.2 \pm 0.1 b$ & $0.1 \pm 0.0 a$ & $0.3 \pm 0.1 a$ & $0.0 \pm 0.0 b$ & $0.1 \pm 0.0 a$ & $0.0 \pm 0.0 \mathrm{~b}$ & $0.0 \pm 0.0 a$ \\
\hline & Muscle-sparing & $0.1 \pm 0.0 b$ & $0.2 \pm 0.1 a$ & $0.1 \pm 0.1 a$ & $0.1 \pm 0.1 a, b$ & $0.1 \pm 0.1 a$ & $0.1 \pm 0.1 b$ & $0.0 \pm 0.0 a$ \\
\hline \multirow{3}{*}{$\begin{array}{l}\text { U } \\
\stackrel{\sim}{ }\end{array}$} & Linea alba & $0.0 \pm 0.0 a$ & $0.0 \pm 0.0 a$ & $0.0 \pm 0.0 a$ & $0.0 \pm 0.0 a$ & $0.0 \pm 0.0 a$ & $0.0 \pm 0.0 a$ & $0.0 \pm 0.0 a$ \\
\hline & Muscle-cutting & $0.0 \pm 0.0 a$ & $0.0 \pm 0.0 a$ & $0.0 \pm 0.0 a$ & $0.0 \pm 0.0 a$ & $0.0 \pm 0.0 a$ & $0.0 \pm 0.0 a$ & $0.0 \pm 0.0 a$ \\
\hline & Muscle-sparing & $0.0 \pm 0.0 a$ & $0.0 \pm 0.0 a$ & $0.0 \pm 0.0 a$ & $0.0 \pm 0.0 a$ & $0.0 \pm 0.0 a$ & $0.0 \pm 0.0 a$ & $0.0 \pm 0.0 a$ \\
\hline
\end{tabular}


Table A.2. ANOVA on mean ranks among incision locations by week at $12^{\circ} \mathrm{C}$ and $20^{\circ} \mathrm{C}$.

\begin{tabular}{|c|c|c|c|c|c|c|c|c|}
\hline \multirow[b]{2}{*}{ Temp. } & \multirow[b]{2}{*}{ Location } & \multicolumn{7}{|c|}{ Day } \\
\hline & & 7 & 14 & 21 & 28 & 35 & 42 & 49 \\
\hline \multirow{3}{*}{$\begin{array}{l}\stackrel{\cup}{\Im} \\
\stackrel{\sim}{\sim}\end{array}$} & Linea alba & $1.4 \pm 0.05 a$ & $1.4 \pm 0.06 a$ & $1.4 \pm 0.06 a$ & $1.3 \pm 0.05 a$ & $1.3 \pm 0.05 a$ & $1.3 \pm 0.06 a$ & $1.2 \pm 0.04 a$ \\
\hline & Muscle-cutting & $3.3 \pm 0.07 b$ & $3.6 \pm 0.07 b$ & $2.2 \pm 0.10 b, c$ & $1.5 \pm 0.08 a$ & $1.4 \pm 0.06 a, b$ & $1.1 \pm 0.03 b, c$ & $1.0 \pm 0.00 b, c$ \\
\hline & Muscle-sparing & $1.8 \pm 0.06 c$ & $2.9 \pm 0.07 c$ & $2.0 \pm 0.09 c$ & $1.4 \pm 0.06 a$ & $1.2 \pm 0.04 a, c$ & $1.1 \pm 0.03 c$ & $1.0 \pm 0.02 c$ \\
\hline \multirow{4}{*}{$\begin{array}{l}\cup \\
\stackrel{\sim}{\nu}\end{array}$} & Linea alba & $1.4 \pm 0.07 a$ & $1.5 \pm 0.07 a$ & $1.4 \pm 0.06 a$ & $1.2 \pm 0.05 a$ & $1.1 \pm 0.02 a$ & $1.0 \pm 0.02 a$ & $1.0 \pm 0.0 a$ \\
\hline & Muscle-cutting & $3.6 \pm 0.06 b$ & $2.4 \pm 0.09 b$ & $1.4 \pm 0.06 a$ & $1.2 \pm 0.04 a$ & $1.0 \pm 0.02 a$ & $1.0 \pm 0.00 a$ & $1.0 \pm 0.0 a$ \\
\hline & Muscle-sparing & $3.0 \pm 0.08 c$ & $2.0 \pm 0.08 b$ & $1.4 \pm 0.06 a$ & $1.2 \pm 0.05 a$ & $1.1 \pm 0.03 a$ & $1.0 \pm 0.00 a$ & $1.0 \pm 0.0 a$ \\
\hline & & 56 & 63 & 70 & 77 & 84 & 91 & 98 \\
\hline \multirow{3}{*}{$\begin{array}{l}\stackrel{\cup}{ } \\
\stackrel{\sim}{\sim}\end{array}$} & Linea alba & $1.2 \pm 0.05 a$ & $1.1 \pm 0.03 a$ & $1.1 \pm 0.04 a$ & $1.1 \pm 0.02 a$ & $1.1 \pm 0.03 a$ & $1.1 \pm 0.03 a$ & $1.1 \pm 0.03 a$ \\
\hline & Muscle-cutting & $1.0 \pm 0.00 b, c$ & $1.0 \pm 0.00 b, c$ & $1.0 \pm 0.00 b, c$ & $1.0 \pm 0.00 b, c$ & $1.0 \pm 0.00 b, c$ & $1.0 \pm 0.00 b, c$ & $1.0 \pm 0.00 b, c$ \\
\hline & Muscle-sparing & $1.0 \pm 0.00 c$ & $1.0 \pm 0.01 c$ & $1.0 \pm 0.01 c$ & $1.0 \pm 0.00 \mathrm{c}$ & $1.0 \pm 0.01 c$ & $1.0 \pm 0.00 \mathrm{C}$ & $1.0 \pm 0.01 c$ \\
\hline \multirow{3}{*}{$\begin{array}{l}\text { ○े } \\
\stackrel{\sim}{\sim}\end{array}$} & Linea alba & $1.0 \pm 0.0 a$ & $1.0 \pm 0.0 a$ & $1.0 \pm 0.0 a$ & $1.0 \pm 0.0 a$ & $1.0 \pm 0.0 a$ & $1.0 \pm 0.0 a$ & $1.0 \pm 0.0 a$ \\
\hline & Muscle-cutting & $1.0 \pm 0.0 a$ & $1.0 \pm 0.0 a$ & $1.0 \pm 0.0 a$ & $1.0 \pm 0.0 a$ & $1.0 \pm 0.0 a$ & $1.0 \pm 0.0 a$ & $1.0 \pm 0.0 a$ \\
\hline & Muscle-sparing & $1.0 \pm 0.0 a$ & $1.0 \pm 0.0 a$ & $1.0 \pm 0.0 a$ & $1.0 \pm 0.0 a$ & $1.0 \pm 0.0 a$ & $1.0 \pm 0.0 a$ & $1.0 \pm 0.0 a$ \\
\hline
\end{tabular}


TableA.3. Logistic regression on proportion of fish with erythema on incisions at $12^{\circ} \mathrm{C}$ and $20^{\circ} \mathrm{C}$.

\begin{tabular}{|c|c|c|c|c|c|c|c|c|c|c|c|c|c|c|c|}
\hline \multirow[b]{2}{*}{ Temp. } & \multirow[b]{2}{*}{ Location } & \multicolumn{14}{|c|}{ Day } \\
\hline & & 7 & 14 & 21 & 28 & 35 & 42 & 49 & 56 & 63 & 70 & 77 & 84 & 91 & 98 \\
\hline \multirow{3}{*}{$\begin{array}{l}\stackrel{\cup}{\circ} \\
\stackrel{\circ}{-}\end{array}$} & Linea alba & $40 \% a$ & $22 \% a$ & $11 \% a$ & $7 \% a$ & $5 \% a$ & $10 \% a$ & $13 \% a$ & $4 \% a$ & $5 \% a$ & $9 \% a$ & $4 \% a$ & $3 \% a$ & $1 \% a$ & $0 \% a$ \\
\hline & Muscle-cutting & $71 \% b$ & $80 \% b$ & $27 \% b$ & $19 \% b$ & $2 \% a$ & $4 \% a, b$ & $1 \% b$ & $0 \% a$ & $1 \% a$ & $1 \% a$ & $1 \% a$ & $0 \% a$ & $0 \% a$ & $0 \% a$ \\
\hline & Muscle-sparing & $64 \% b$ & $49 \%$ c & $15 \% a$ & $7 \% a$ & $1 \% a$ & $2 \% b$ & $4 \% b$ & $1 \% a$ & $3 \% a$ & $3 \% a$ & $1 \% a$ & $1 \% a$ & $0 \% a$ & $0 \% a$ \\
\hline \multirow{3}{*}{$\begin{array}{l}0 \\
: \\
\stackrel{\sim}{N}\end{array}$} & Linea alba & $63 \% a$ & $28 \% a$ & $16 \% a$ & $8 \% a$ & $2 \% a$ & $0 \% a$ & $0 \% a$ & $0 \% a$ & $0 \% a$ & $0 \% a$ & $0 \% a$ & $0 \% a$ & $0 \% a$ & $0 \% a$ \\
\hline & Muscle-cutting & $68 \% a$ & $14 \% b$ & $2 \% b$ & $3 \% a, b$ & $1 \% a$ & $0 \% a$ & $0 \% a$ & $0 \% a$ & $0 \% a$ & $0 \% a$ & $0 \% a$ & $0 \% a$ & $0 \% a$ & $0 \% a$ \\
\hline & Muscle-sparing & $51 \% b$ & $9 \% b$ & $6 \% b$ & $2 \% b$ & $1 \% a$ & $0 \% a$ & $0 \% a$ & $0 \% a$ & $0 \% a$ & $0 \% a$ & $0 \% a$ & $0 \% a$ & $0 \% a$ & $0 \% a$ \\
\hline
\end{tabular}

ن

Table A.4. Logistic regression on proportion of fish with incision closure at $12^{\circ} \mathrm{C}$ and $20^{\circ} \mathrm{C}$.

\begin{tabular}{|c|c|c|c|c|c|c|c|c|c|c|c|c|c|c|c|}
\hline \multirow[b]{2}{*}{ Temp. } & \multirow[b]{2}{*}{ Location } & \multicolumn{14}{|c|}{ Day } \\
\hline & & 7 & 14 & 21 & 28 & 35 & 42 & 49 & 56 & 63 & 70 & 77 & 84 & 91 & 98 \\
\hline \multirow{3}{*}{ 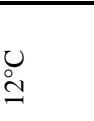 } & Linea alba & $0.0 \% a$ & $0.0 \% a$ & $0.0 \% a$ & $50 \% a$ & $65 \% a, b$ & $60 \% a$ & $66 \% a$ & $78 \% a$ & $80 \% a$ & $78 \% a$ & $82 \% a$ & $82 \% a$ & $83 \% a$ & $88 \% a$ \\
\hline & Muscle-cutting & $0.0 \% a$ & $0.0 \% a$ & $0.0 \% a$ & $30 \% b$ & $55 \% a$ & $68 \% a$ & $78 \% a$ & $89 \%$ a & $88 \% a$ & $96 \% b$ & $96 \% b$ & $98 \% b$ & $98 \% b$ & $98 \% a$ \\
\hline & Muscle-sparing & $0.0 \% a$ & $0.0 \% a$ & $0.0 \% a$ & $38 \% b$ & $76 \% b$ & $80 \% b$ & $90 \% b$ & $95 \% b$ & $94 \% a$ & $95 \% b$ & $95 \% b$ & $97 \% b$ & $99 \% b$ & $99 \% a$ \\
\hline \multirow{3}{*}{ 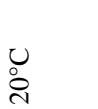 } & Linea alba & $0.0 \% a$ & $13 \%$ a & $44 \%$ a & $77 \% a$ & $92 \% a$ & $94 \% a$ & $97 \%$ a & $97 \% a$ & $98 \% a$ & $99 \% a$ & $100 \% a$ & $100 \% a$ & $100 \% a$ & $100 \% a$ \\
\hline & Muscle-cutting & $0.0 \% a$ & $7 \% b$ & $24 \% a$ & $79 \% a$ & $93 \% a$ & $96 \% a$ & $97 \% a$ & $96 \% a$ & $99 \%$ a & $99 \%$ a & $100 \% a$ & $100 \% a$ & $100 \% a$ & $100 \% a$ \\
\hline & Muscle-sparing & $0.0 \% a$ & $8 \% b$ & $22 \% a$ & $83 \% a$ & $88 \% a$ & $95 \%$ a & $99 \%$ a & $98 \% a$ & $100 \% a$ & $100 \% a$ & $100 \% a$ & $100 \% a$ & $100 \% a$ & $100 \% a$ \\
\hline
\end{tabular}


Table A.5. ANOVA on mean number of sutures retained by fish at $12^{\circ} \mathrm{C}$ and $20^{\circ} \mathrm{C}$.

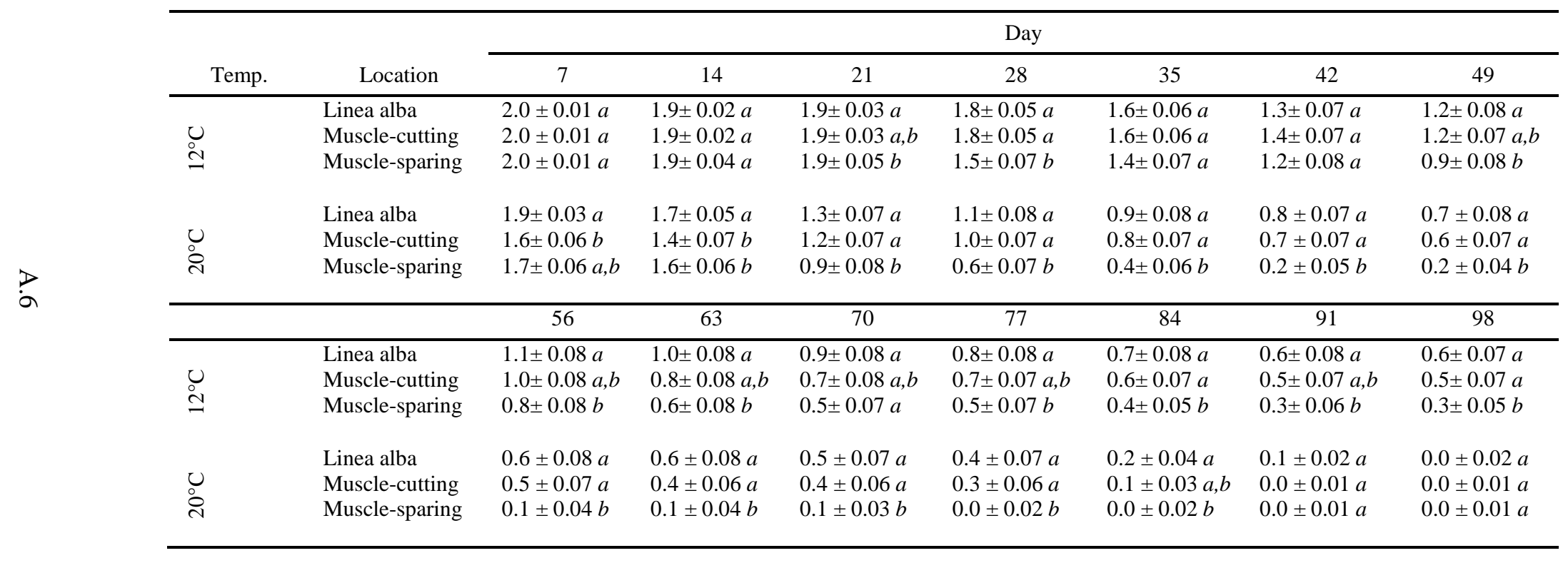




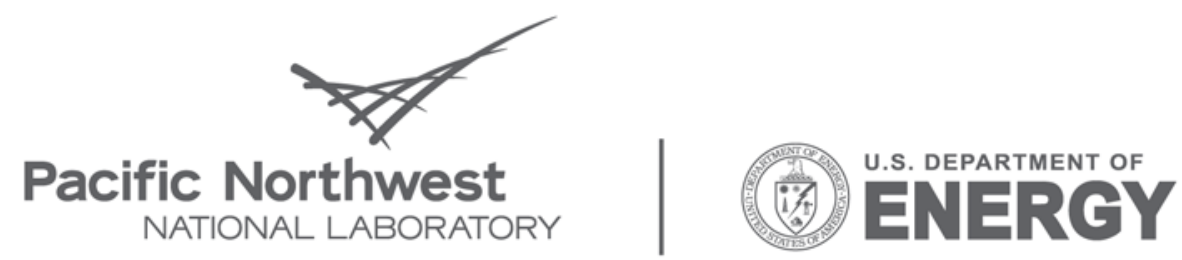

Proudly Operated by Battelle Since 1965

902 Battelle Boulevard

P.O. Box 999

Richland, WA 99352

1-888-375-PNNL (7665)

www.pnl.gov 